Acknowledgment. We are grateful to NSF for support of this research under Grant CHE8800813. We also thank Mr. Xin Min Yang for assistance with several experiments.

Supplementary Material Available: Tables of positional and anisotropic thermal parameters for 4 (Tables II and III), 13
(Tables VI and VII), and 17 (Tables X and XI), a full tabulation of important bond distances and angles for 4,13 , and 17, and Figures 1, 6, and 7 (39 pages); listings of observed and calculated structure factors from the final cycle of least-squares refinement (92 pages). Ordering information is given on any current masthead page.

\title{
Intrazeolite Metal Carbonyl Topotaxy. A Comprehensive Structural and Spectroscopic Study of Intrazeolite Group VI Metal Hexacarbonyls and Subcarbonyls
}

\author{
Saim Özkar, ${ }^{\dagger, \ddagger}$ Geoffrey A. Ozin, ${ }^{*, \downarrow}$ Karin Moller, ${ }^{\S}$ and Thomas Bein ${ }^{\S}$ \\ Contribution from the Lash Miller Chemistry Department, University of Toronto, Toronto, \\ Ontario, Canada MSS IAl, and Department of Chemistry, University of New Mexico, \\ Albuquerque, New Mexico 87131. Received January 3, 1990
}

\begin{abstract}
This paper focuses attention on the intrazeolite anchoring, thermal decarbonylation, ligand exchange, and addition chemistry of $\mathrm{M}(\mathrm{CO})_{6}-\mathrm{M}_{56}^{\prime} \mathrm{Y}$, where $\mathrm{M}=\mathrm{Cr}, \mathrm{Mo}, \mathrm{W} ; \mathrm{M}^{\prime}=\mathrm{H}, \mathrm{Li}, \mathrm{Na}, \mathrm{K}, \mathrm{Rb}, \mathrm{Cs}$. The key points to emerge from this study include the following. (i) $\mathrm{M}(\mathrm{CO})_{6}-\mathrm{M}_{56}^{\prime} \mathrm{Y}$ samples have the hexacarbonylmetal(0) molecule associated with two $\alpha$-cage extraframework cations (or Brønsted protons), via the oxygen end of two trans bonded carbonyls with a saturation loading of $2 \mathrm{M}(\mathrm{CO})_{6} / \alpha$-cage. (ii) $\mathrm{M}(\mathrm{CO})_{6}-\mathrm{M}^{\prime}{ }_{56} \mathrm{Y}$ samples have the hexacarbonylmetal( 0 ) guest confined to the internal surface of the zeolite with a homogeneous distribution throughout the zeolite crystals. (iii) A Mo and Rb EXAFS structure analysis of $8\left\{\mathrm{Mo}(\mathrm{CO})_{6}\right\}-\mathrm{Rb}_{56} \mathrm{Y}$ shows that the $\alpha$-cage encapsulated $\mathrm{Mo}(\mathrm{CO})_{6}$ guest maintains its structural integrity, with some evidence for anchoring via extraframework $\mathrm{Rb}^{+}$cations. (iv) A rapid ${ }^{13} \mathrm{CO}$ intrazeolite ligand exchange occurs for $\mathrm{M}\left({ }^{12} \mathrm{CO}\right)_{6}-\mathrm{M}_{56}^{\prime} \mathrm{Y}$ to yield $\mathrm{M}\left({ }^{12} \mathrm{CO}\right)_{m}\left({ }^{13} \mathrm{CO}\right)_{6-m}-\mathrm{M}_{56}^{\prime} \mathrm{Y}$, the extent of which depends on the ${ }^{13} \mathrm{CO}$ loading. (v) $\mathrm{M}(\mathrm{CO})_{3}-\mathrm{M}_{56}{ }_{56} \mathrm{Y}$ can be cleanly generated via the mild vacuum thermal decarbonylation of $\mathrm{M}(\mathrm{CO})_{6}-\mathrm{M}_{56}^{\prime} \mathrm{Y}$, the tricarbonyl stoichiometry of which is unequivocally established from its observed and calculated diagnostic $\mathrm{M}\left({ }^{12} \mathrm{CO}\right)_{n}\left({ }^{13} \mathrm{CO}\right)_{3-n}-\mathrm{M}_{56}^{\prime} \mathrm{Y}$ vibrational isotope pattern and from EXAFS structural data. (vi) Intrazeolite reactions of $\mathrm{M}(\mathrm{CO})_{3}-\mathrm{M}_{56}{ }_{56} \mathrm{Y}$ with large and small arenes, trienes, and phosphines cleanly yield the respective intrazeolite six-coordinate complexes (shown to be identical with the products of direct impregnation of the latter complexes), thereby supporting the tricarbonylmetal( 0 ) assignment as well as pinpointing the location of the $\mathrm{M}(\mathrm{CO})_{3}-\mathrm{M}_{36} \mathrm{Y}$ tricarbonylmetal(0) fragment on the internal surface of the zeolite. (vii) Cation effects in the mid/far-IR, EXAFS data, and optical reflectance spectra indicate that the supercage-confined $\mathrm{M}(\mathrm{CO})_{3}-\mathrm{M}^{\prime}{ }_{56} \mathrm{Y}$ moiety is anchored to an oxygen framework site rather than to an extraframework cation site via the metal or oxygens of the carbonyls. (viii) The tricarbonyl fragments show $C_{s}$ and $C_{3 v}$ symmetry depending on the choice of $\mathrm{M}$ and $\mathrm{M}^{\prime}$ which can be rationalized in terms of a second-order Jahn-Teller effect. (ix) EXAFS data for the mild thermal decomposition of $\mathrm{Mo}(\mathrm{CO})_{3}-\mathrm{Rb}_{56} \mathrm{Y}$ demonstrates the formation of molybdenum atoms statistically distributed in the zeolite lattice.
\end{abstract}

\section{Introduction}

Organometallics and coordination compounds strategically located and anchored within the cage and channel spaces of different zeolite structure types possess the ability to organize and effect catalytic and electrochemical transformations, artificial photosynthesis, gas separation/purification, and vectorial electron transport processes with molecule size/shape specificity.' While volatile organometallics are now routinely used as precursors for the fabrication of device quality semiconductor nanostructures using epitaxial MOCVD and photoepitaxy, ${ }^{2}$ it is only very recently that they have been intentionally utilized to create organized assemblies of intrazeolite semiconductor quantum crystallites. ${ }^{3}$ Intrazeolite organometallic (photo)topotaxy could provide a useful inroad to the chemical synthesis of semiconductor quantum dot, wire, and supralattice nanostructures with possible applications as quantum electronic and nonlinear optical devices. ${ }^{4}$

This paper focuses on simple binary metal carbonyls for the eventual growth and stabilization of intrazeolite semiconductor quantum structures. ${ }^{\text {sa }}$ The rationale for selecting this particular group of precursors relates to their volatility, molecular dimensions,

\footnotetext{
${ }^{+}$On sabbatical leave from the Chemistry Department, Middle East Technical University, Ankara, Turkey.

University of Toronto.

University of New Mexico.
}

ease of purification, availability, and facile and quantitative conversion to the respective metal oxide materials with minimal contamination by carbon. ${ }^{5 a, b}$

In this particular investigation we direct attention to the following: (i) anchoring site details of $\mathrm{M}(\mathrm{CO})_{6}$ in $\mathrm{M}_{56}^{\prime} \mathrm{Y}$ (where $\mathrm{M}=\mathrm{Cr}, \mathrm{Mo}, \mathrm{W} ; \mathrm{M}^{\prime}=\mathrm{H}, \mathrm{Li}, \mathrm{Na}, \mathrm{K}, \mathrm{Rb}, \mathrm{Cs}$ ), (ii) internal versus external confinement and the homogeneity of $\mathrm{M}(\mathrm{CO})_{6}-\mathrm{M}^{\prime}{ }_{56} \mathrm{Y}$, (iii) ${ }^{13} \mathrm{CO}$ isotope substitution chemistry of $\mathrm{M}(\mathrm{CO})_{6}-\mathrm{M}^{\prime}{ }_{56} \mathrm{Y}$, (iv) vacuum thermal decarbonylation chemistry of $\mathrm{M}(\mathrm{CO})_{6}-\mathrm{M}_{56}^{\prime} \mathrm{Y}$ to $\mathrm{M}(\mathrm{CO})_{3}-\mathrm{M}_{56}^{\prime} \mathrm{Y},(\mathrm{v}){ }^{12} \mathrm{CO} /{ }^{13} \mathrm{CO}$ mixed isotopic proof of the $\mathrm{M}\left({ }^{12} \mathrm{CO}\right)_{n}\left({ }^{13} \mathrm{CO}\right)_{3-n}-\mathrm{M}_{56}^{\prime} \mathrm{Y}$ stoichiometry, (vi) location and identity of $\mathrm{M}(\mathrm{CO})_{3}-\mathrm{M}^{\prime}{ }_{56} \mathrm{Y}$ via arene, triene, and phosphine size exclusion chemical reactions, (vii) an EXAFS determination of

(1) Ozin, G. A.; Gil, C. Chem. Rev. 1989, 89, 1749 and references cited therein.

(2) Almond, M. J.; Rice, D. A.; Yates, C. A. Chem. Br. 1988, $24,1130$.

(3) Ozin, G. A.; Kuperman, A.; Stein, A. Adv. Mater. 1989, 101, 373. Stucky, G. D.; MacDougall, J. Science 1990, 247, 669, and references cited therein.

(4) Brus, L. E., et al.J. Mater. Res. 1989, 4, 704.

(5) (a) Ozin, G. A.; Özkar, S. J. Phys. Chem. 1990, 94, 7556. Ozin, G. A.; Özkar, S.; Macdonald, P. J. Phys. Chem. 1990, 94, 6939. (b) Herrmann, W. A. J. Organomet. Chem. 1986, 300, 111. Angew. Chem., Int. Ed. Engl. 1988, 27, 1297. Almond, M. J.; Crayston, J. A.; Downs, A. J.; Poliakoff, M.; Turner, J. Inorg. Chem. 1986, 25, 19-25, and references cited therein. 
the attachment site of the $\mathrm{Mo}(\mathrm{CO})_{3}$ fragment in the exemplary system $\mathrm{Mo}(\mathrm{CO})_{3}-\mathrm{Rb}_{56} \mathrm{Y}$.

\section{Experimental Section}

Materials. The high purity, crystalline sodium zeolite $\mathrm{Y}$ with the unit cell composition $\mathrm{Na}_{56}\left(\mathrm{AlO}_{2}\right)_{56}\left(\mathrm{SiO}_{2}\right)_{136^{*}} \times \mathrm{H}_{2} \mathrm{O}$ was obtained from Dr. Edith Flanigen at Union Carbide, Tarrytown, NY. To remove cation defect sites, thermally dehydrated/calcined $\mathrm{Na}_{56} \mathrm{Y}$ was slurried with 0.01 $\mathrm{M} \mathrm{NaCl}, 0.01 \mathrm{M} \mathrm{NaOH}$ solution and washed until free of $\mathrm{Cl}^{-}$. Other alkali-metal zeolites $\mathrm{M}^{\prime}{ }_{56} \mathrm{Y}$ (where $\mathrm{M}^{\prime}=\mathrm{Li}, \mathrm{K}, \mathrm{Rb}, \mathrm{Cs}$ ) as well as $\left(\mathrm{NH}_{4}\right)_{56} \mathrm{Y}$ and $\mathrm{H}_{56} \mathrm{Y}$ were prepared by the use of standard ion-exchange techniques and deammination procedures ${ }^{6}$ Far-IR spectra of the alkali-metal zeolites used indicated essentially complete ion exchange. ${ }^{7}$ All zeolite samples were stored over saturated $\mathrm{NH}_{4} \mathrm{Cl}$ solution to ensure a constant humidity until use. $\mathrm{M}(\mathrm{CO})_{6}$ (where $\mathrm{M}=\mathrm{Cr}, \mathrm{Mo}, \mathrm{W}$ ) and $\mathrm{Cr}(\mathrm{CO})_{3}\left(\eta^{6}-\mathrm{C}_{6} \mathrm{H}_{6}\right)$ were purchased from Strem Chemicals Inc., Newbury-Port, $\mathrm{MA}$. $\mathrm{Mo}(\mathrm{CO})_{3}\left(\eta^{6}-1,3,5-\mathrm{C}_{7} \mathrm{H}_{8}\right)$ was synthesized according to the standard preparative technique. ${ }^{8}$ Experimental details concerning spectroscopic cells and equipment, IR, UV-vis, XRD, XPS, MAS-NMR, and EXAFS measurements as well as CHEM-X molecular modelling are collected together in the supplementary material.

Extended X-ray Absorption Fine Structure Spectroscopy. EXAFS experiments were performed at the X-3 beamline at NSLS (National Synchrotron Light Source, Brookhaven National Laboratories) with an electron energy of $2.5 \mathrm{GeV}$ and ring currents between 80 and $140 \mathrm{~mA}$. Data were collected of $\mathrm{Rb} /$ Mo containing zeolite samples in transmission with a $\mathrm{Si}(111)$ crystal pair monochromator at the Mo absorption edge $(20000 \mathrm{eV})$ as well as the $\mathrm{Rb}$ absorption edge $(15200 \mathrm{eV})$ at ca. $100 \mathrm{~K}$. Data analysis was performed following standard procedures.9 Backscattering amplitude and phase functions used in the least-square-fitting routine were extracted from the following reference materials (Table I): $\mathrm{Mo}(\mathrm{CO})_{6}$ was used for $\mathrm{Mo}-\mathrm{C}$ and $\mathrm{Mo}-\mathrm{CO}$ contributions, $\mathrm{Na}_{2} \mathrm{MoO}_{4}$ for $\mathrm{Mo}-\mathrm{O}, \mathrm{Rb}_{2} \mathrm{O}$ for $\mathrm{Rb}-\mathrm{O}$, and $\mathrm{GaP}$ for $\mathrm{Rb}-\mathrm{Si}$ and $\mathrm{Rb}-\mathrm{Rb}$ interactions. Mo foil $(0.025 \mathrm{~mm})$ and $\mathrm{MoO}_{2}$ were measured as standards for edge positions. Zeolite powders were embedded in an octadecane/eicosane mixture and kept under a nitrogen atmosphere until data collection. The following samples were measured:

sample names

treatment

(Rb/Mo absorption edge)

$\mathrm{RbY}$

$\mathrm{RbMo6} / \mathrm{Mo6Rb}$

dehydrated $\mathrm{Rb}_{56}\left(\mathrm{AlO}_{2}\right)_{56}\left(\mathrm{SiO}_{2}\right)_{136}$

$\mathrm{RbY}$ loaded with $\mathrm{Mo}(\mathrm{CO})_{6}, 1$ molecule per supercage

$\mathrm{RbMo3} / \mathrm{Mo3Rb}$ above sample treated at $130^{\circ} \mathrm{C}$ for 20 min in vacuum

$\mathrm{RbMoM} / \mathrm{MoMRb}$ as RbMo3, heated further at $250^{\circ} \mathrm{C}$ for $30 \mathrm{~min}$ in vacuum

Experimental Procedure. About $20 \mathrm{mg}$ of size-sieved zeolite crystals are pressed into a self-supporting wafer with a diameter of $16 \mathrm{~mm}$ by applying a pressure of 5 tons per square in. for $10 \mathrm{~s}$. The disks are secured in the stainless steel sample holder and placed in the quartz part of the cell. The thermal dehydration of the wafer under dynamic vacuum, by using an Omega Series CN-2010 programmable temperature controller, follows a preset temperature schedule; $25-100^{\circ} \mathrm{C}$ over $1 \mathrm{~h}$, I h at $100^{\circ} \mathrm{C}, 100-450^{\circ} \mathrm{C}$ over $3 \mathrm{~h}$, and $1 \mathrm{~h}$ at $450^{\circ} \mathrm{C}$. This was followed by calcination in a static atmosphere of 300 Torr of oxygen at $450^{\circ} \mathrm{C}$ for $1 \mathrm{~h}$ and pumping hot at this temperature. The degree of dehydration was judged by the flatness of the base line in the IR $\nu \mathrm{OH}$ stretching and $\delta \mathrm{OH}$ deformation regions, $3400-3700$ and $1600-1650$ $\mathrm{cm}^{-1}$, respectively. When a sufficiently dehydrated sample was obtained, the wafer was moved into place above the organometallic sample holder. By opening the stopcock to the sample holder, exposure to the organometallic vapor under dynamic vacuum was continued until an absorbance of 2-3 units was obtained in the carbonyl mid-IR region corresponding to a loading of about $0.5-1.0 \mathrm{M}(\mathrm{CO})_{6}$ molecules per $\alpha$-cage. Reaction times varied from $5 \mathrm{~s}$ for $\mathrm{Cr}(\mathrm{CO})_{6}$ to $30 \mathrm{~s}$ for $\mathrm{Mo}(\mathrm{CO})_{6}$ and $\mathrm{W}(\mathrm{CO})_{6}$ at room temperature. For vapor-phase impregnation of $\mathrm{Cr}(\mathrm{CO})_{3}\left(\eta^{6}-\mathrm{C}_{6} \mathrm{H}_{6}\right)$ and $\mathrm{Mo}(\mathrm{CO})_{3}\left(\eta^{6}-1,3,5-\mathrm{C}_{7} \mathrm{H}_{8}\right)$ external heating of the samples was required. This was accomplished by warming the organometallic sample holder in a water bath at temperatures between 60 and $70^{\circ} \mathrm{C}$ for $5-10$ min. Further thermal treatments were carried out under dynamic vac-

(6) Dwyer, J.; Dyer, A.Chem. Ind 1984, 237, and references cited therein (7) Ozin, G. A.; Godber, J. G.; Baker, M. D. Catal. Rev. Sci. Eng. 1985, $27,591$.

(8) A bel, E. W.; Bennet, M. A.; Burton, R.; Wilkinson, G. J. Chem. Soc. 1958,4559

(9) Lee, P. A.; Citrin, P. H.; Eisenberger, P.; Kincaid, B. M. Rev. Modern Phys. 1981, 53, 769 . uum by using a temperature-controlled furnace. Thermal decarbonylation of $\mathrm{M}(\mathrm{CO})_{6}-\mathrm{M}_{56}^{\prime} \mathrm{Y}$ to $\mathrm{M}(\mathrm{CO})_{3}-\mathrm{M}_{56}^{\prime} \mathrm{Y}$ was achieved by heating the sample for $30 \mathrm{~min}$ under dynamic vacuum at $100^{\circ} \mathrm{C}$ for $\mathrm{M}=\mathrm{Cr}$ and $130^{\circ} \mathrm{C}$ for $\mathrm{M}=\mathrm{Mo}, \mathrm{W}$. The complete decarbonylation to $\mathrm{M}_{n}-\mathrm{M}^{\prime} \mathrm{Y}$ was obtained by further heating the sample at temperatures above $150^{\circ} \mathrm{C}$ under dynamic vacuum for $30 \mathrm{~min}$. The intrazeolite complexes $\mathrm{M}$ $(\mathrm{CO})_{3} \mathrm{~L}_{3}-\mathrm{M}^{\prime}{ }_{56} \mathrm{Y}\left(\mathrm{M}=\mathrm{Cr}, \mathrm{Mo}, \mathrm{W} ; \mathrm{L}_{3}=3 \mathrm{CO}, 3 \mathrm{PMe}_{3}, \mathrm{C}_{6} \mathrm{H}_{6}\right.$, and $\left.1,3,5-\mathrm{C}_{7} \mathrm{H}_{8}\right)$ were formed by exposing the $\mathrm{M}(\mathrm{CO})_{3}-\mathrm{M}_{56}^{\prime} \mathrm{Y}$ sample to the respective ligand following heating to $150^{\circ} \mathrm{C}$ in the case of $\mathrm{PMe}_{3}$.

${ }^{12} \mathrm{CO} /{ }^{13} \mathrm{CO}$ isotope exchange reactions were carried out either by UV irradiation of the $\mathrm{M}(\mathrm{CO})_{6}-\mathrm{M}_{36}^{\prime} \mathrm{Y}$ sample in a static pressure of $50 \mathrm{Torr}$ of a ${ }^{12} \mathrm{CO}:{ }^{13} \mathrm{CO}$ mixture with various ratios at room temperature for 2 $\mathrm{h}$ or by heating the same sample at $90^{\circ} \mathrm{C}$ for $2 \mathrm{~h}$.

Calculated $\nu \mathrm{CO}$ frequencies and $\mathrm{C}-\mathrm{O}$ bond stretching/interaction force constants were obtained with the programs of McIntosh and Peterson ${ }^{13}$ by using $F$ and $G$ matrices for a tricarbonylmetal $(0)$ moiety having $C_{s}$ or $C_{3 v}$ symmetry together with use of the Cotton-Kraihanzel force field approximation. ${ }^{14}$

Elemental analyses for $\mathrm{Na}, \mathrm{Al}, \mathrm{Cr}, \mathrm{Mo}$, and $\mathrm{W}$ were performed by Neutron Activation analysis on the $U$ of Toronto Slow Poke Reactor.

\section{Results and Discussion}

Sorption of $\mathbf{M}(\mathrm{CO})_{6}$ into Zeolite $\mathrm{Y}$. (a) Unannealed Samples. Hexacarbonylmetal $(0), M(C O)_{6}(M=C r, M o, W)$, sorbed from the vapor phase into fully ion-exchanged, defect removed, calcined, and vacuum thermally dehydrated $\mathrm{M}^{\prime}{ }_{56} \mathrm{Y}\left(\mathrm{Si} / \mathrm{Al}=2.5, \mathrm{M}^{\prime}=\mathrm{Li}\right.$, $\mathrm{Na}, \mathrm{K}, \mathrm{Rb}, \mathrm{Cs}$ ) displays the characteristic pattern of $\nu \mathrm{CO}$ stretching modes for an octahedral symmetry molecule slightly perturbed by interaction with an extraframework cation(s) (supplementary material Figure 1). Similar results have been reported for $\mathrm{Mo}(\mathrm{CO})_{6}$ in $\mathrm{Na}_{56} \mathrm{Y}$ and $\mathrm{H}_{56} \mathrm{Y}^{15}$ One can determine from these spectra that the IR active $\nu \mathrm{CO} \mathrm{T}_{2}$ solid/solution/ gas-phase frequency range for all three $\mathrm{M}(\mathrm{CO})_{6}$ species 2003-1977 $\mathrm{cm}^{-1}$ is red-shifted following sorption into alkali metal zeolite $Y$, to now yield a dominant $\nu \mathrm{CO}$ absorption lying in the range 1979-1962 $\mathrm{cm}^{-1}$ (supplementary material Table II). These spectral shifts and IR activities signal the presence of a "nonspecific", weak interaction between the extraframework cations of the zeolite and the $\mathrm{CO}$ ligand(s) of the hexacarbonylmetal( 0$)$ guest. The $\mathrm{M}(\mathrm{CO})_{6}-\mathrm{M}_{96}{ }_{96} \mathrm{Y}$ IR spectra of supplementary material Figure 1 are essentially invariant to $\mathrm{M}(\mathrm{CO})_{6}$ loading over the range of $0.1-16$ hexacarbonylmetal $(0)$ molecules per unit cell of zeolite $\mathrm{Y}$ (recall that there are eight $\alpha$-cages per unit cell). The value of $16 \mathrm{M}(\mathrm{CO})_{6} /$ unit cell, namely $2 \mathrm{M}(\mathrm{CO})_{6} / \alpha$-cage, represents the analytical figure obtained for "saturation loading" and agrees with earlier measurements on related systems (see later).

Thermal evacuation of these samples anywhere in the temperature range room temperature to $50^{\circ} \mathrm{C}$ has little effect on the IR spectra shown in supplementary material Figure 1 indicating that the $\mathrm{M}(\mathrm{CO})_{6}$ guest is associated with extraframework cations and confined to the internal surface of the zeolite $Y$ rather than weakly physisorbed to the external surface of the crystals. ${ }^{1,16}$ Note that $O_{h} \mathrm{M}(\mathrm{CO})_{6}$ molecules have kinetic diameters in the range of 5.3-5.5 $\AA \times 7.4-7.6 \AA$ (supplementary material Table II) and can therefore gain free access to the $13-\AA$ diameter $\alpha$-cage through the 7.8-8.0- $\AA$ diameter 12-ring entrance port of zeolite $Y .{ }^{17}$ By contrast, $\mathrm{K}_{8} \mathrm{Na}_{4} \mathrm{~A}$ has only a $3-\AA$ diameter eight-ring entrance window to its $11-\AA$ diameter $\alpha$-cage ${ }^{17}$ and effectively restricts the location of $\mathrm{M}(\mathrm{CO})_{6}$ to the external surface of the zeolite $A$ crystals.

(10) Arnesen, S. P.; Seip, H. M. Acta Chem. Scand. 1966, 20, 2711. (11) Matsumoto, K.; Kobayashi, A.; Sasaki, Y. Bull. Chem. Soc. Jpn. $1975,48,1009$

(12) Strukturbericht 1941, 7, 85

(13) McIntosh, D. F.; Peterson, M. R. Programs No. 342, BMat, FTRY/ ATOM, FFIT; Quantum Chemistry Program Exchange, Room 204, Indiana University, Bloomington, IN, 47401 .

(14) Cotton, F. A.; Kraihanzel, C. S. J. Am. Chem. Soc. 1962, 84, 4432. (15) Abdo, S.; Howe, R. F. J. Phys. Chem. 1983, 87, 1713. You-Sing, Y.; Howe, R. F. J. Chem. Soc., Faraday Trans. l, 1986, 82, 2887. Okamoto, Y.; Maezawa, A.; Kane, H.; Mitsushima, I.; Imanaka, T. J. Chem. Soc, Faraday Trans. 1988, 84, 85 I. Coddington, J. H.; Howe, R. F.; Yong, Y. S.; Asakara, K.; Iwasawa, Y. J. Chem. Soc., Faraday Trans. 1990, 86(6), 1015.

(16) Godber, J.; Ozin, G. A. J. Phys. Chem. 1989, 93, 878. Gil, C.; Haddleton, D.; Ozin, G. A. J. Phys. Chem. 1989, 43, 6710.

(17) Breck, D. W. Zeolite Molecular Sieves; Wiley: New York, 1974. 


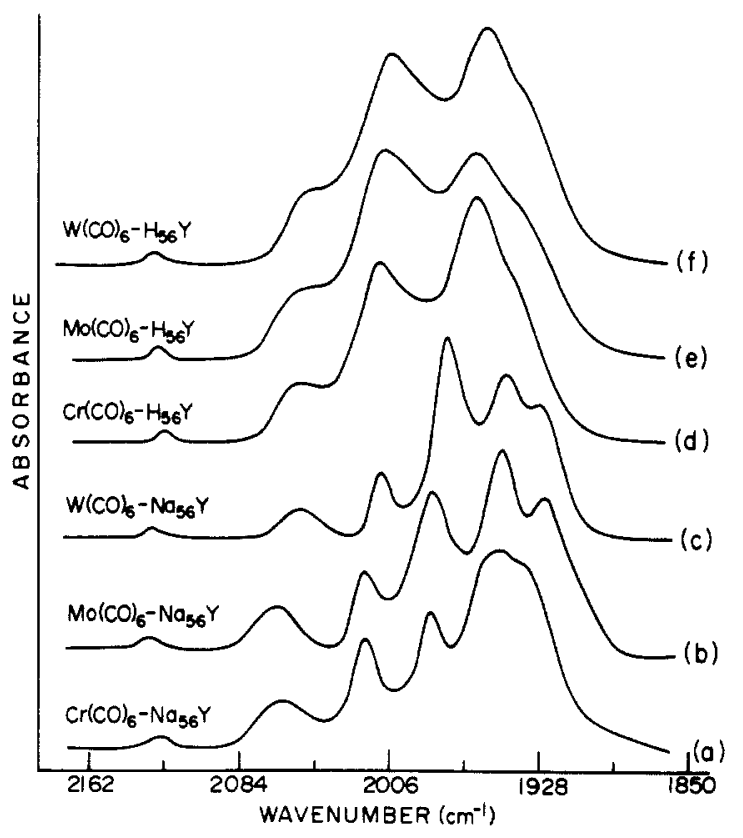

Figure 1. The mid-IR spectra of the annealed samples of (a) $\mathrm{Cr}$ (C$\mathrm{O})_{6}-\mathrm{Na}_{56} \mathrm{Y}$, (b) $\mathrm{Mo}(\mathrm{CO})_{6}-\mathrm{Na}_{56} \mathrm{Y}$, (c) $\mathrm{W}(\mathrm{CO})_{6}-\mathrm{Na}_{56} \mathrm{Y}$, (d) $\mathrm{Cr}(\mathrm{CO})_{6}-$ $\mathrm{H}_{56} \mathrm{Y}$, (e) $\mathrm{Mo}(\mathrm{CO})_{6}-\mathrm{H}_{36} \mathrm{Y}$, and (ก) W(CO) ${ }_{6}-\mathrm{H}_{56} \mathrm{Y}$.

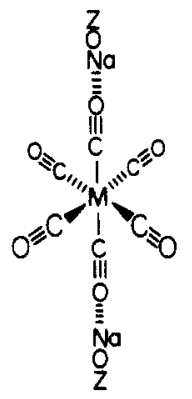

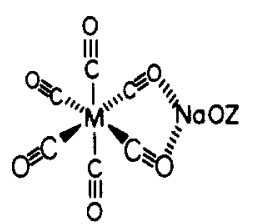

trans-ZONam $\mathrm{OCW}(\mathrm{CO})_{4} \mathrm{CO} \times \mathrm{NaOZ}$

cis- $-\mathrm{ZONan}(\mathrm{CO})_{2} \mathrm{~W}(\mathrm{CO})_{4}$

Figure 2. Anchoring site models for the hexacarbonylmetal $(0)$ complex in the alkali metal zeolite $\mathrm{Y}$.

Our experiments demonstrate that the latter can be readily detached from the crystals simply by a brief room-temperature evacuation. ${ }^{16}$

(b) Annealed Samples. Thermal annealing of hexacarbonylmetal(0) guests in, for example, $\mathrm{Na}_{56} \mathrm{Y}$ in the range $50-80^{\circ} \mathrm{C}$ causes a smooth transformation of the IR spectra of freshly impregnated samples depicted in supplementary material Figure 1, to ones characteristic of a single, structurally well-defined species (Figure la-c) best described as the anchoring site model in which the $O_{h}$ symmetry of the free $\mathrm{M}(\mathrm{CO})_{6}$ molecule is reduced to $C_{20}$ (or lower) by interaction of the oxygen end of two trans carbonyl ligands (i.e., two opposite apices of the $\mathrm{M}(\mathrm{CO})_{6}$ octahedron) with two extraframework $\alpha$-cage $\mathrm{Na}^{+}$cations, namely, trans$\mathrm{ZONa} \ldots \mathrm{OCM}(\mathrm{CO}){ }_{4} \mathrm{CO} \ldots \mathrm{NaOZ}$, illustrated in Figure 2.

The thinking behind this statement of structure/binding of $\mathrm{M}(\mathrm{CO})_{6}$ at the extraframework alkali metal site of attachment relates to the following: (a) The observed $\nu \mathrm{CO}$ stretching modes generally indicate a trend of blue-shifting with decreasing ionic potential (charge/radius) $\left(Z^{*} / r\right)$ of the cation where $\Delta \nu_{\mathrm{CO}}\left(\mathrm{Li}^{+}\right.$ to $\left.\mathrm{Cs}^{+}\right) \simeq 10 \mathrm{~cm}^{-1} .16$ (b) Six well-defined $\nu \mathrm{CO}$ absorptions (supplementary material Table III) for the annealed $\mathrm{M}(\mathrm{CO})_{6}-$ $\mathrm{M}^{\prime}{ }_{56} \mathrm{Y}$ samples are observed to evolve out of the single dominant "pseudo $\nu \mathrm{CO} \mathrm{T}_{2}$ " band of the unannealed samples and maintain the same intensity ratio from run-to-run after the annealing post-treatment and over the complete $\mathrm{M}(\mathrm{CO})_{6}$ loading range up to saturation values of $2 \mathrm{M}(\mathrm{CO})_{6} / \alpha$-cage investigated in this study. (c) IR activity for ALL SIX possible vibrational degrees of freedom of six $\nu \mathrm{CO}$ oscillators requires loss of all vibrational degeneracy of the $\nu \mathrm{CO}$ modes of $\mathrm{M}(\mathrm{CO})_{6}-\mathrm{M}_{56}{ }_{56} \mathrm{Y}$.

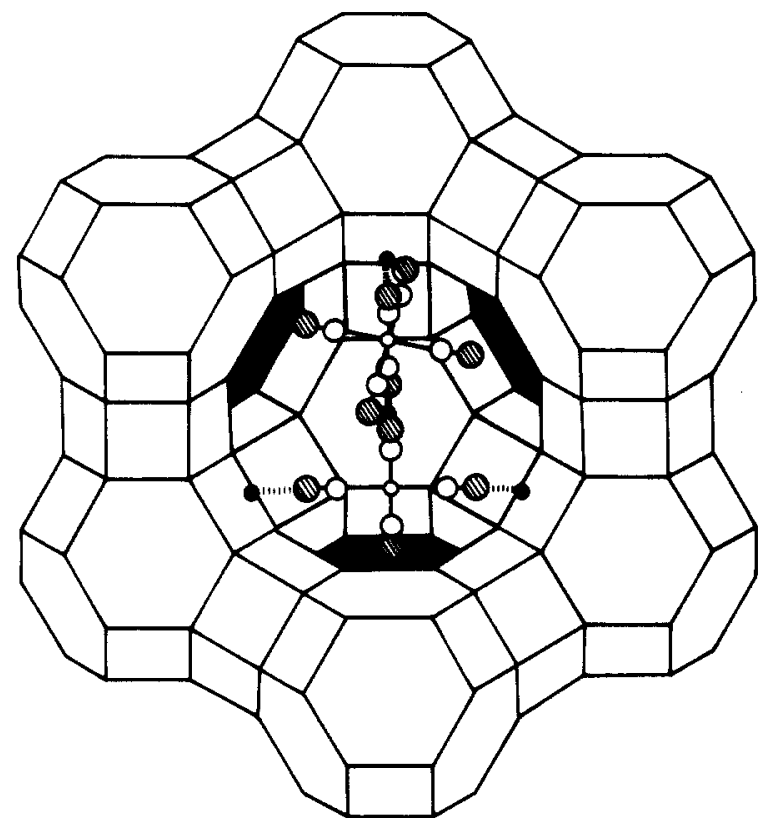

Figure 3. CHEM-X model for two $\alpha$-cage immobilized trans-ZONa... $\mathrm{OCW}(\mathrm{CO})_{4} \mathrm{CO} \cdots \mathrm{NaOZ}$ moieties involving adjacent $\mathrm{Na}^{+}$site II cation six-ring binding sites.

The above observations together with the determination of a maximum filling of $2 \mathrm{M}(\mathrm{CO})_{6} / \alpha$-cage leads one to propose an anchoring site geometry in which the original $O_{h}$ symmetry of the free molecule is reduced to $C_{2 v}$ or lower through involvement of the oxygen end of two trans carbonyl ligands with the extraframework $\mathrm{Na}^{+} \alpha$-cage cations as depicted in Figure 2 . This binding site model is preferred for steric reasons over the alternative one involving the interaction of the oxygen end of two cis carbonyl ligands (i.e., an edge of the $\mathrm{M}(\mathrm{CO})_{6}$ octahedron) with a single extraframework $\alpha$-cage cation, that is, cis-ZONa... $(\mathrm{OC})_{2} \mathrm{M}(\mathrm{CO})_{4}$, also illustrated in Figure 2. Credance for the trans-ZONa $\cdots(\mathrm{OC}) \mathrm{M}(\mathrm{CO})_{4}(\mathrm{CO}) \ldots \mathrm{NaOZ}$ anchoring site model with a maximum loading of $2 \mathrm{M}(\mathrm{CO})_{6} / \alpha$-cage could be usefully evaluated by using the molecular modelling and energy minimization routines available on the CHEM-X software package, and procedures of the type described in the supplementary material Experimental Section of this paper. One finds that the steric and volume filling requirements of $\alpha$-cage encapsulated $\mathrm{M}(\mathrm{CO})_{6}$ having minimal nonbonded repulsions favors the aforementioned trans-ZONa... $\mathrm{OCM}(\mathrm{CO})_{4} \mathrm{CO} \cdots \mathrm{NaOZ}$ structure having a colinear $\mathrm{Na}$... OCMCO... $\mathrm{Na}$ skeleton involving two adjacent $\mathrm{Na}^{+}$site II cations, with minimum $r(\mathrm{Na}$... OC) distances of 2.6-2.9 $\AA$ ( $\mathrm{M}=$ $\mathrm{Cr}, \mathrm{Mo}, \mathrm{W}$ ) and a maximum confinement number of $2 \mathrm{M}$ $(\mathrm{CO})_{6} / \alpha$-cage. An example of one of the CHEM-X graphic illustrations obtained for $16 \mathrm{~W}(\mathrm{CO})_{6}-\mathrm{Na}_{56} \mathrm{Y}$ is shown in Figure 3.

(c) EXAFS Study of $8\left\{\mathrm{Mo}(\mathrm{CO})_{6}\right\}-\mathrm{Rb}_{56} \mathrm{Y}$. EXAFS analysis is capable of providing direct structural information of zeolite-occluded complexes and can in principle detect major symmetry changes and/or coordination of metal carbonyls to extraframework ions. As an example, EXAFS measurements were performed of a $\mathrm{Rb}_{56} \mathrm{Y}$ sample loaded with one $\mathrm{Mo}(\mathrm{CO})_{6}$ molecule per supercage, $8\left\{\mathrm{Mo}(\mathrm{CO})_{6}\right\}-\mathrm{Rb}_{56} \mathrm{Y}$. The rubidium-molybdenum system was chosen, to allow a convenient study of BOTH metal absorption edges. Thus, possible interactions between $\mathrm{Rb}$ cations and the molybdenum carbonyl could be probed.

Fourier transformed EXAFS data of sample Mo6Rb (Mo absorption edge) are shown in supplementary material Figure $2 \mathrm{~b}$. The first and second shell of this sample represent the carbon and oxygen atoms of the carbonyl ligands, respectively. A visual comparison with data of the crystalline $\mathrm{Mo}(\mathrm{CO})_{6}$ precursor (supplementary material Figure $2 a$ ) indicates that the molecule remains intact upon adsorption into the zeolite cages. A fit of the first and second shell of sample Mo6Rb was done separately with the precursor as reference. Fit results are shown in supplementary material Figure 2c,d. As listed in Table II a carbon 
Table I. Fourier Transformation Ranges and Crystallographic Data of Reference Compounds

\begin{tabular}{lcccccc}
\hline \multicolumn{1}{c}{ ref } & $k^{n}$ & $\Delta k\left(\AA^{-1}\right)$ & $\Delta R(\AA)$ & $R(\AA)$ & $N$ & ref \\
\hline $\mathrm{Mo}(\mathrm{CO})_{6}$ & 1 & $3.0-11.7$ & $0.0-1.66$ & 2.063 & 6 & 10 \\
& & & $2.2-3.00$ & 3.208 & 6 & \\
$\mathrm{Na}_{2} \mathrm{MoO}_{4}$ & 1 & $3.7-15.9$ & $0.0-1.76$ & 1.772 & 4 & 11 \\
$\mathrm{RbF}$ & 1 & $2.8-12.5$ & $0.0-2.86$ & 2.82 & 6 & 12 \\
$\mathrm{RbCl}$ & 3 & $2.1-13.8$ & $2.2-3.2$ & 3.27 & 6 & 12 \\
\hline
\end{tabular}

Table II. Structural Data as Derived from EXAFS Analysis

\begin{tabular}{|c|c|c|c|c|c|}
\hline sample & atom pair & $\overline{N^{a}}$ & $R^{b}(\AA)$ & $\Delta \sigma^{2 c}\left(\AA^{2}\right)$ & $\Delta E^{d}(\mathrm{eV}$ \\
\hline \multicolumn{6}{|c|}{ Mo EDGE } \\
\hline \multirow[t]{2}{*}{ Mo6Rb } & $\mathrm{Mo}-\mathrm{CO}$ & 6 & 2.06 & -0.0012 & 0.5 \\
\hline & $\mathrm{Mo}-\overline{\mathrm{CO}}$ & 8.1 & 3.21 & 0.0028 & -0.9 \\
\hline \multirow[t]{2}{*}{ Mo3Rb } & $\begin{array}{c}\mathrm{Mo}-\mathrm{CO}+ \\
\mathrm{Mo}-\mathrm{O}\end{array}$ & (see text) & $\begin{array}{c}\text { ca. } 1.93 \AA+ \\
1.82 \AA\end{array}$ & & \\
\hline & $\mathrm{Mo}-\mathrm{CO}$ & $4.3(3.4)^{e}$ & 3.06 & 0.0017 & -0.2 \\
\hline MoMRb & $\mathrm{Mo}-\mathrm{C} / \mathrm{O}$ & 0.6 & 2.08 & -0.004 & -4.5 \\
\hline \multicolumn{6}{|c|}{ Rb EDGE } \\
\hline $\mathrm{RbY}$ & $\begin{array}{l}\mathrm{Rb}-\mathrm{O} \\
\mathrm{Rb}-\mathrm{Si} / \mathrm{Al}\end{array}$ & $\begin{array}{l}2.6 \\
(1.7 y\end{array}$ & $\begin{array}{l}2.75 \\
3.59\end{array}$ & $\begin{array}{l}0.000 \\
0.000\end{array}$ & $\begin{array}{r}9.4 \\
-4.3\end{array}$ \\
\hline \multirow[t]{2}{*}{ RbMo6 } & $\mathrm{Rb}-\mathrm{O}$ & 2.8 & 2.77 & 0.003 & 8.8 \\
\hline & $\mathrm{Rb}-\mathrm{Si} / \mathrm{Al}$ & 2.9 & 3.59 & 0.002 & -4.2 \\
\hline \multirow[t]{2}{*}{ RbMo3 } & $\mathrm{Rb}-\mathrm{O}$ & 2.7 & 2.76 & 0.000 & 7.4 \\
\hline & $\mathrm{Rb}-\mathrm{Si} / \mathrm{Al}$ & 2.1 & 3.60 & 0.002 & -4.2 \\
\hline \multirow[t]{2}{*}{ RbMoM } & $\mathrm{Rb}-\mathrm{O}$ & 1.8 & 2.76 & -0.003 & 6.8 \\
\hline & $\mathrm{Rb}-\mathrm{Si} / \mathrm{Al}$ & 2.3 & 3.58 & 0.000 & -4.5 \\
\hline
\end{tabular}

${ }^{a}$ Coordination number. ${ }^{b}$ Bond distance. 'Static disorder. ${ }^{d}$ Inner potential. 'When fitted with internal standard Mo6Rb (see text). ${ }^{f}$ The limited phase transferability of the first shell scatterer $\mathrm{RbF}$ as reference for the second shell $\mathrm{Rb}-\mathrm{Si}$ samples precludes the accurate determination of coordination numbers.

coordination number $N$ of 6 is found with a bond length of 2.06 $\AA$, which is identical with that of solid molybdenum( 0 ) hexacarbonyl at $2.063 \AA$. Similarly, the distance of the oxygen of the carbonyl ligand is identical with the reference, i.e., $3.21 \AA$. However, a Mo-C $-\underline{O}$ coordination number of 8.1 is found. For the interpretation of the latter one has to consider that in colinear structures such as $\mathrm{M}-\mathrm{C}-\mathrm{O}$, the outgoing photoelectron is strongly forward scattered, which results in a significant amplitude enhancement. This effect drops off rapidly with bond angles $<150^{\circ}$, and it can actually be exploited to estimate these angles. ${ }^{18}$ It is likely that the high coordination number found in sample Mo6Rb reflects a slightly bent arrangement of the $\mathrm{CO}$ ligands in the crystalline reference compound, which thereby results in an artifically high value in the analyzed sample. Since the first shell fit, which is not affected by this focus effect, results in six carbon ligands, the number of oxygen atoms is accordingly limited to six.

A possible interaction of intrazeolite $\mathrm{Mo}(\mathrm{CO})_{6}$ with rubidium cations of the zeolite can be probed with rubidium edge EXAFS data, which are shown in supplementary material Figure 3 . The Fourier transformed data of the empty rubidium exchanged zeolite as well as those of the $\mathrm{Mo}(\mathrm{CO})_{6}$ loaded sample appear to be very similar. An overlay of the imaginary part of the RbY precursor and the RbMo6 sample (not shown) indicates small differences in the first shell of the distribution function. Quantitative results were obtained by fitting this first shell of both samples with $\mathrm{Rb}_{2} \mathrm{O}$. In the precursor sample, 2.8 oxygen ligands are detected at a distance of $2.89 \AA$ (supplementary material Figure 3c, Table II). The second shell originates from zeolite $\mathrm{Si} / \mathrm{Al}$ atoms at a distance of $3.45 \AA$ (supplementary material Figure $3 \mathrm{~d}$; this shell cannot be fitted with a metal-metal interaction as would occur in rubidium oxide). In sample RbMo6, the oxygen coordination number is increased to 3.3 , accompanied by a slight bond elongation to $2.91 \AA$ and a relatively higher static disorder. The $\mathrm{Rb}-\mathrm{Si}$ coordination is unchanged compared to the precursor sample. These results suggest that the $\mathrm{Rb}$ ions are mainly located in six ring positions of the zeolite. The small changes in coordination

(18) Teo, B. K. J. Am. Chem. Soc. 1981, 103, 3390.

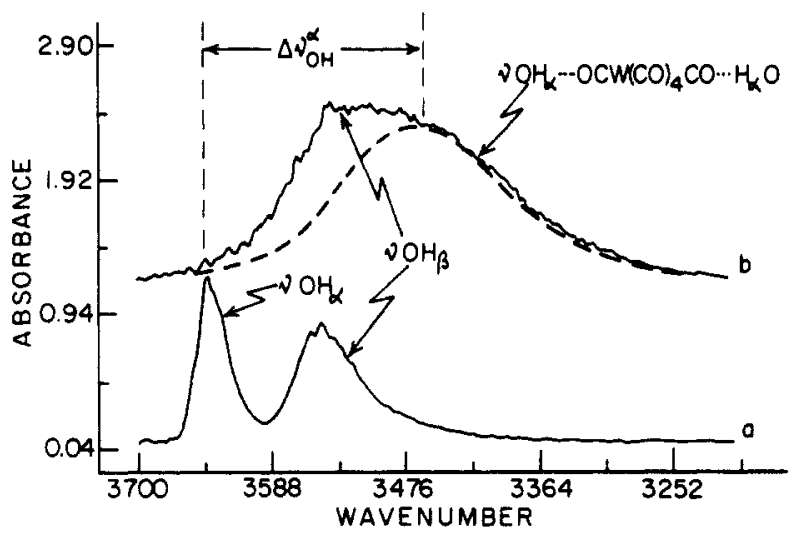

Figure 4. The mid-IR spectra of $\mathrm{H}_{56} \mathrm{Y}$ (a) dehydrated and (b) fully saturated with $\mathrm{W}(\mathrm{CO})_{6}$, that is, $2 \mathrm{~W}(\mathrm{CO})_{6} / \alpha$-cage, $16 \mathrm{~W}(\mathrm{CO})_{6} /$ unit cell; internal versus external confinement and homogeneity probes. ${ }^{1}$

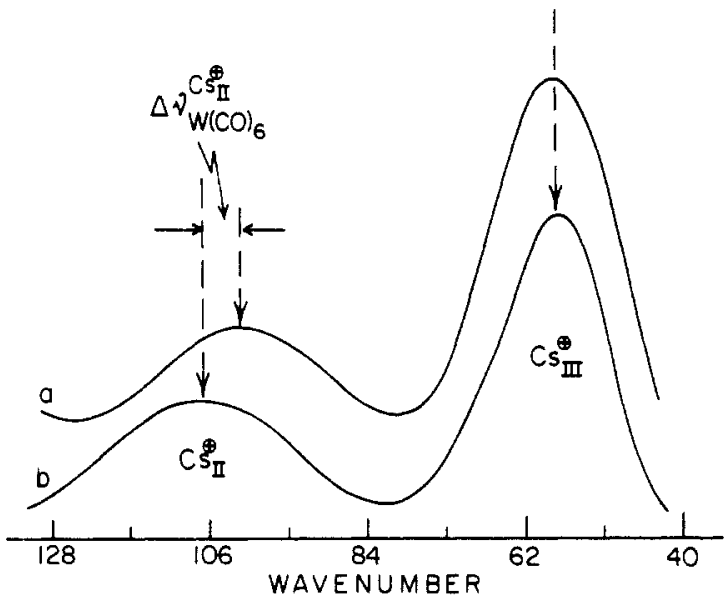

Figure 5. The far-IR spectra of (a) dehydrated $\mathrm{CS}_{36} \mathrm{Y}$ and (b) $\mathrm{W}(\mathrm{CO})_{6}-\mathrm{Cs}_{56} \mathrm{Y} . \Delta \nu$ denotes adsorption induced far-IR cation translatory mode frequency shift; internal versus external confinement and homogeneity probes.

numbers may indicate a slight cation redistribution upon uptake of $\mathrm{Mo}(\mathrm{CO})_{6}$ and a weak, disordered interaction with the carbonyl ligands. Moderate outer-shell scattering at ca. $4 \AA$ observed in the Mo data (Figure 2b; no correction for phase shifts) could indicate this interaction between carbonyl ligands and $\mathrm{Rb}$ ions. This outer-shell scattering is not observed with the fragment $\mathrm{Mo}(\mathrm{CO})_{3}$ (Figure $9 \mathrm{a}$, supplementary material). It is difficult to make a positive discrimination between these possibilities, since only 8-16 rubidium ions of 56 per unit cell would encounter a change in their ligand sphere upon interaction with the eight $\mathrm{Mo}(\mathrm{CO})_{6}$ molecules per unit cell.

(d) Control Experiments for $\mathbf{M}(\mathbf{C O})_{6}-\mathbf{M}_{56}^{\prime} \mathbf{Y}$. Control powder XRD, ${ }^{29} \mathrm{Si}$ MAS-NMR, XPS, and mid- and far-IR experiments (Figures 4 and 5), which provide evidence for maintenance of the crystallinity and framework integrity of the zeolite $Y$ crystals at all stages, for internal versus external housing of $\mathrm{M}(\mathrm{CO})_{6}$ guests and for sorption homogeneity, are described in detail in the supplementary material section of this paper.

$\mathrm{M}(\mathrm{CO})_{3}-\mathbf{M}_{56}^{\prime} \mathbf{Y}$. (a) Thermal Decarbonylation of $\mathbf{M}(\mathrm{CO})_{6}-$ $\mathbf{M}_{56}^{\prime} \mathbf{Y}$. The in situ thermal vacuum decarbonylation of $\mathbf{M}$ $(\mathrm{CO})_{6}-\mathrm{M}^{\prime}{ }_{56} \mathrm{Y}$ at $100-150^{\circ} \mathrm{C}$ can be organized to proceed through what appears to be TWO intermediate stages to cleanly produce a single subcarbonyl species (denoted $\mathrm{M}(\mathrm{CO})_{3}-\mathrm{M}_{56}{ }_{56} \mathrm{Y}$ ) whose mid-IR diagnostic is typically (see later) three strong $\nu \mathrm{CO}$ absorption bands:

$$
\mathrm{M}(\mathrm{CO})_{6}-\mathrm{M}_{56}^{\prime} \mathrm{Y} \underset{\text { in vacuo }}{\stackrel{100-150^{\circ} \mathrm{C}}{\longrightarrow}} \mathrm{M}(\mathrm{CO})_{3}-\mathrm{M}^{\prime}{ }_{56} \mathrm{Y}
$$

(Note that the $\nu \mathrm{CO}$ spectral patterns, growth and decay behavior, and comparison with similar literature data, ${ }^{15}$ for the two reactive intermediates mentioned above, indicate that they are best ascribed to the $\mathrm{M}(\mathrm{CO})_{4,5}-\mathrm{M}^{\prime}{ }_{56} \mathrm{Y}$ subcarbonylmetal(0) species. Spectral 


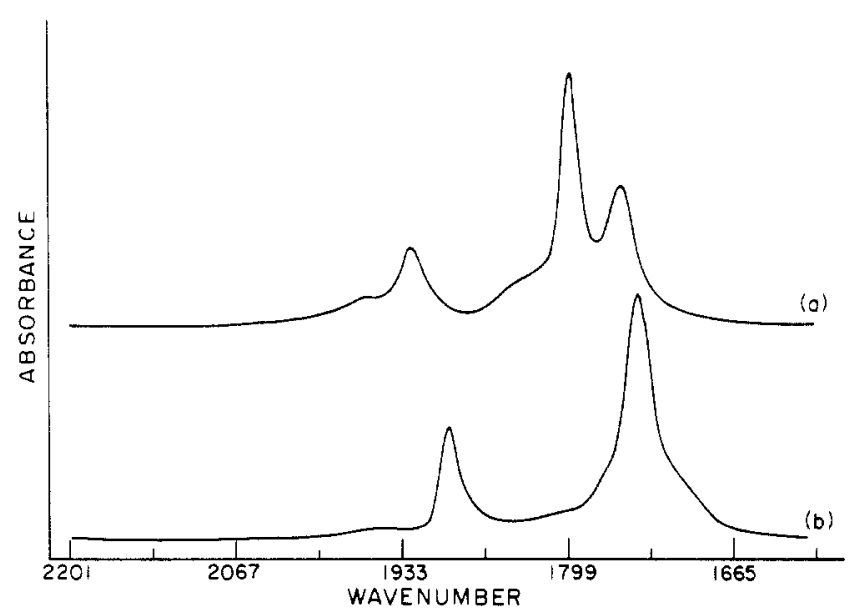

Figure 6. The mid-IR spectra of $\mathrm{M}(\mathrm{CO})_{3}-\mathrm{M}_{56}^{\prime} \mathrm{Y}$ where (a) $\mathrm{M}=\mathrm{Mo}$, $M^{\prime}=\mathrm{Li}$ and (b) $\mathrm{M}=\mathrm{W}, \mathrm{M}^{\prime}=\mathrm{Cs}$.

overlap complications, however, preclude unequivocal identification of their stoichiometry and structure, so we shall not pursue them further here; instead we will focus attention on the spectrally clean $\mathrm{M}(\mathrm{CO})_{3}-\mathrm{M}_{56}^{\prime} \mathrm{Y}$ species.)

A representative trace of the $\mathrm{M}(\mathrm{CO})_{3}-\mathrm{M}_{56}^{\prime} \mathrm{Y}$ species generated from a $\mathrm{Mo}(\mathrm{CO})_{6}-\mathrm{Li}_{56} \mathrm{Y}$ sample is illustrated in Figure $6 \mathrm{a}$. The complete set of data for the $3 \times 5$ matrix of $15 \mathrm{M}(\mathrm{CO})_{3}-\mathrm{M}_{56}^{\prime} \mathrm{Y}$ species derived from $\mathrm{M}(\mathrm{CO})_{6}-\mathrm{M}_{56} \mathrm{Y}$ is laid out in supplementary material Table IV. It is especially noteworthy that only in the case of the $\mathrm{M}(\mathrm{CO})_{3}-\mathrm{M}_{56}^{\prime} \mathrm{Y}$ species formed from $\mathrm{Mo}(\mathrm{CO})_{6}-\mathrm{Cs}_{56} \mathrm{Y}$ and $\mathrm{W}(\mathrm{CO})_{6}-\mathrm{Cs}_{56} \mathrm{Y}$ is a mid-IR spectrum observed that displays two strong $\nu \mathrm{CO}$ bands (Figure $6 \mathrm{~b}$ ) instead of three (Figure 6a). In essence the TWO closely spaced lower frequency $\nu \mathrm{CO}$ modes of the latter group have collapsed into ONE for the former group (supplementary material Table IV). It is important to note that these two classes of mid-IR $\nu \mathrm{CO}$ patterns (associated with $C_{30}$ and $C_{s}$ tricarbonyl symmetries, see later) are reproducible from run-to-run and are invariant to thermal annealing post-treatments of the $\mathrm{M}(\mathrm{CO})_{3}-\mathrm{M}_{56}{ }_{56} \mathrm{Y}$ zeolite $\mathrm{Y}$ samples. The spectra shown in Figure 6, supplementary material Table IV depict the existence of two distinct thermally equilibriated forms of the same $M(C O)_{3}$ subcarbonyl moiety in zeolite $Y$.

(b) Stoichiometry of $\mathbf{M}(\mathbf{C O})_{3}-\mathbf{M}_{56} \mathbf{Y}$. One chemically logical way to identify the "persistent" subcarbonyl species (Figure 6) is by way of trapping experiments using, for example, tridentate ligands. To exemplify the method one can employ benzene or 1,3,5-cycloheptatriene having kinetic diameters of 5.9 and $6.1 \AA$, respectively (supplementary material Table II), both of which can gain facile access to the $\alpha$-cage of zeolite $\mathrm{Y}$, where the subcarbonyl is most likely to be housed.

In practice one finds that the reaction of $\mathrm{M}(\mathrm{CO})_{3}-\mathrm{M}_{56}{ }_{56} \mathrm{Y}$ with $\mathrm{C}_{6} \mathrm{H}_{6}$ and $\mathrm{C}_{7} \mathrm{H}_{8}$ cleanly yields as products $\mathrm{M}(\mathrm{CO})_{3}\left(\eta^{6}-\mathrm{C}_{6} \mathrm{H}_{6}\right)-$ $\mathrm{M}_{56}^{\prime} \mathrm{Y}$ and $\mathrm{M}(\mathrm{CO})_{3}\left(\eta^{6}-1,3,5-\mathrm{C}_{7} \mathrm{H}_{8}\right)-\mathrm{M}_{56}^{\prime} \mathrm{Y}$, respectively. These intrazeolitically generated complexes, which can be considered to form by capping the tricarbonyl moiety with the arene or triene ligands, respectively, were most convincingly identified by comparing their mid-IR spectra with those independently obtained by subliming the known $\mathrm{M}(\mathrm{CO})_{3}\left(\eta^{6}-\mathrm{C}_{6} \mathrm{H}_{6}\right)$ and $\mathrm{M}(\mathrm{CO})_{3}\left(\eta^{6}\right.$ 1,3,5-C $\mathrm{C}_{7} \mathrm{H}_{8}$ ) complexes, respectively, into the same zeolite $\mathrm{Y}$. The results of these two procedures yielded intrazeolite products displaying identical mid-IR diagnostics. A typical example is illustrated in Figure 7. The results of these tests are summarized below

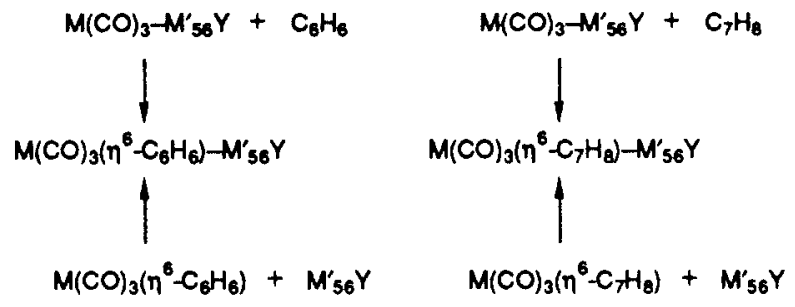

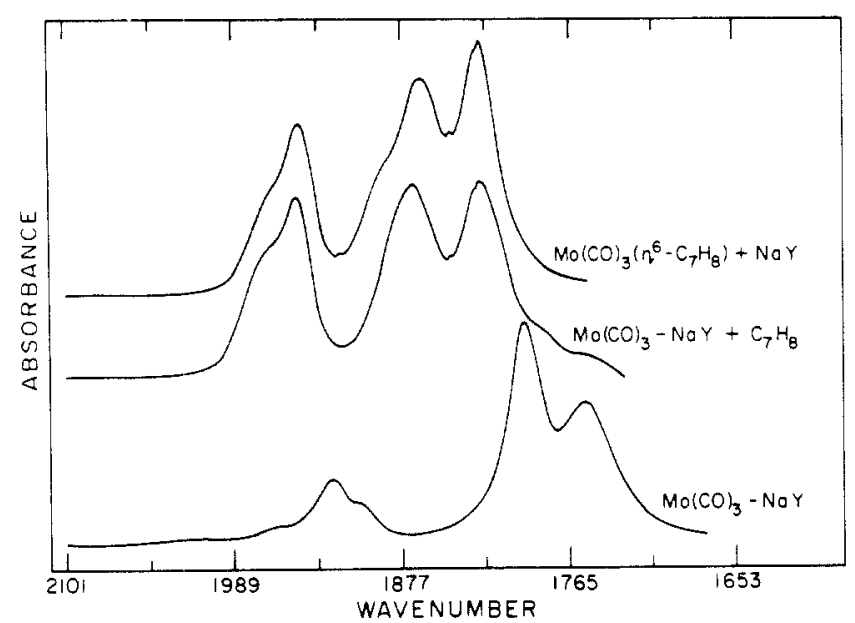

Figure 7. The mid-IR spectra of $\mathrm{Mo}(\mathrm{CO})_{3}-\mathrm{Na}_{56} \mathrm{Y}$ and $\mathrm{Mo}(\mathrm{CO})_{3}\left(\eta^{6}-\right.$ 1,3,5- $\left.\mathrm{C}_{7} \mathrm{H}_{8}\right)-\mathrm{Na}_{56} \mathrm{Y}$ generated by the reaction of $\mathrm{Mo}(\mathrm{CO})_{3}-\mathrm{Na}_{56} \mathrm{Y}$ with $1,3,5$-cycloheptatriene in the zeolite or by direct sublimation of Mo$(\mathrm{CO})_{3}\left(\eta^{6}-1,3,5-\mathrm{C}_{7} \mathrm{H}_{8}\right)$ into the zeolite.

and can be considered to provide indirect proof of the tricarbonylmetal $(0)$ stoichiometry of the intrazeolite "persistent" subcarbonyl moiety created by the vacuum thermal decarbonylation of $\mathrm{M}(\mathrm{CO})_{6}-\mathrm{M}_{56}^{\prime} \mathrm{Y}$. Direct proof for this proposal stems from mixed isotope labeling experiments described in the following sections.

(c) ${ }^{13} \mathrm{CO}$ Exchange Reactions of Intrazeolite $\mathrm{M}(\mathrm{CO})_{6}-\mathrm{M}_{56}{ }_{56} \mathrm{Y}$. In order to define the stoichiometry of the proposed $\mathrm{M}(\mathrm{CO})_{3}-$ $\mathrm{M}^{\prime}{ }_{56} \mathrm{Y}$ intrazeolite subcarbonyl unit by using ${ }^{12} \mathrm{CO} /{ }^{13} \mathrm{CO}$ mixed isotope labeling techniques, one has to first selectively ${ }^{12} \mathrm{CO} /{ }^{13} \mathrm{CO}$ label the intrazeolite precursor hexacarbonylmetal $(0)$ moiety. It turns out that this is most easily accomplished by conducting a thermal $\left(90^{\circ} \mathrm{C}\right.$ ) or photochemical (room temperature, $\lambda>240-\mathrm{nm}$ broadband) reaction of intrazeolite $\mathrm{M}\left({ }^{12} \mathrm{CO}\right)_{6}-\mathrm{M}_{56}{ }_{56} \mathrm{Y}$ with ${ }^{13} \mathrm{CO}$ by using a pressure of 50 Torr. Over a period of $2 \mathrm{~h}$ the ${ }^{12} \mathrm{CO} /{ }^{13} \mathrm{CO}$ exchange reaction proceeds rapidly and smoothly through all of the intermediately labeled hexacarbonylmetal $(0)$ isotopic species $\mathrm{M}\left({ }^{12} \mathrm{CO}\right)_{m}\left({ }^{13} \mathrm{CO}\right)_{6-m}-\mathrm{M}_{56}^{\prime} \mathrm{Y}$ (where $\left.m=0-6\right)$ to finally yield clean samples of fully ${ }^{13} \mathrm{CO}$ labeled $\mathrm{M}\left({ }^{13} \mathrm{CO}\right)_{6}-\mathrm{M}^{\prime}{ }_{56} \mathrm{Y}$. A representative illustration of this intrazeolite ${ }^{12} \mathrm{CO} /{ }^{13} \mathrm{CO}$ ligand isotope exchange reaction is shown for $\mathrm{W}\left({ }^{12} \mathrm{CO}\right)_{m}\left({ }^{13} \mathrm{CO}\right)_{6-m}-\mathrm{Cs}_{56} \mathrm{Y}$ in supplementary material Figure 4 . With the ability to curtail the ${ }^{12} \mathrm{CO} /{ }^{13} \mathrm{CO}$ isotope exchange reaction for intrazeolite $\mathrm{M}$ $\left({ }^{12} \mathrm{CO}\right)_{m}\left({ }^{13} \mathrm{CO}\right)_{6-m}-\mathrm{M}_{56}^{\prime} \mathrm{Y}$ at any value of $m$, we are now poised to probe the carbonyl stoichiometry of the proposed $\mathrm{M}\left({ }^{12} \mathrm{CO}\right)_{n}$ $\left({ }^{13} \mathrm{CO}\right)_{3-n}-\mathrm{M}_{56}^{\prime} \mathrm{Y}$ tricarbonyl moiety (where $n=0-3$ ).

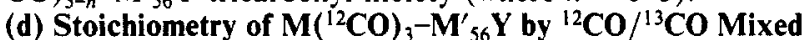
Isotope Labeling Techniques. The $\mathrm{W}\left({ }^{12} \mathrm{CO}\right)_{m}\left({ }^{13} \mathrm{CO}\right)_{6-m}-\mathrm{Cs}_{56} \mathrm{Y}$ and $\mathrm{Mo}\left({ }^{12} \mathrm{CO}\right)_{m}\left({ }^{13} \mathrm{CO}\right)_{6-m}-\mathrm{Li}_{56} \mathrm{Y}$ systems provide ideal test cases for elucidating the carbonyl stoichiometry of the proposed $C_{3 v}$ and $C_{s}$ tricarbonylmetal $(0)$ intermediates formed by the in situ thermal decarbonylation of the intrazeolite hexacarbonylmetal $(0)$ represented by the equation

$$
\mathrm{M}\left({ }^{12} \mathrm{CO}\right)_{m}\left({ }^{13} \mathrm{CO}\right)_{6-m}-\mathrm{M}_{56}^{\prime} \mathrm{Y} \underset{\text { in vacuo }}{\stackrel{100-150{ }^{\circ} \mathrm{C}}{\longrightarrow}\left({ }^{12} \mathrm{CO}\right)_{n}\left({ }^{13} \mathrm{CO}\right)_{3-n}-\mathrm{M}_{56}^{\prime} \mathrm{Y}}
$$

(i) The $C_{3 v} \mathrm{~W}\left({ }^{12} \mathrm{CO}\right)_{n}\left({ }^{13} \mathrm{CO}\right)_{3-n}-\mathrm{Cs}_{56} \mathrm{Y}$ System. The two strong $\mathrm{A}_{1}+\mathrm{E} \nu \mathrm{CO}$ stretching modes of the proposed $C_{3 v}$ symmetry $\mathrm{W}\left({ }^{12} \mathrm{CO}\right)_{3}-\mathrm{Cs}_{56} \mathrm{Y}$ intrazeolite tricarbonylmetal $(0)$ complex are observed at 1895 and $1741 \mathrm{~cm}^{-1}$, respectively (Figure 6b). The ${ }^{12} \mathrm{CO} /{ }^{13} \mathrm{CO}$ mixed isotopic $\nu \mathrm{CO}$ vibrational patterns for $\mathrm{W}$ $\left({ }^{12} \mathrm{CO}\right)_{n}\left({ }^{13} \mathrm{CO}\right)_{3-n}-\mathrm{Cs}_{56} \mathrm{Y}$ species for $1,30,40,50,60,80,96$, and $100 \%{ }^{13} \mathrm{CO}$ enrichment are shown for both the $\mathrm{A}_{1}$ and $\mathrm{E} \nu \mathrm{CO}$ bands in Figure 8. The extent of ${ }^{13} \mathrm{CO}$ enrichment was determined from the degree of ${ }^{13} \mathrm{CO}$ exchange in the $\mathrm{W}\left({ }^{12} \mathrm{CO}\right)_{m^{-}}$ $\left({ }^{13} \mathrm{CO}\right)_{6-m}-\mathrm{Cs}_{56} \mathrm{Y}$ (supplementary material Figure 4). A close examination of these mixed isotopic $\nu C O$ IR spectra reveals the diagnostic isotopic quartet patterns on both the high- and lowfrequency $A_{1}$ and $E{ }_{\nu} \mathrm{CO}$ stretching fundamentals of the sub- 
Table III. Observed and Calculated $\nu \mathrm{CO}$ Frequencies $\left(\mathrm{cm}^{-1}\right)$ of $C_{30}$ Regular Trigonal-Pyramidal $\mathrm{W}\left({ }^{12} \mathrm{CO}\right)_{n}\left({ }^{13} \mathrm{CO}\right)_{3-n}-\mathrm{Cs}_{56} \mathrm{Y}^{0}$

\begin{tabular}{llll}
\hline \multicolumn{1}{c}{ species } & obsd & calcd & assignment \\
\hline $\mathrm{W}\left({ }^{12} \mathrm{CO}\right)_{3}-\mathrm{Cs}_{56} \mathrm{Y}$ & 1895 & 1892 & $\mathrm{~A}_{1}$ \\
$\left(C_{30}\right)$ & 1741 & 1738 & $\mathrm{E}$ \\
$\mathrm{W}\left({ }^{12} \mathrm{CO}\right)_{2}\left({ }^{13} \mathrm{CO}\right)-\mathrm{Cs}_{56} \mathrm{Y}$ & 1880 & 1880 & $\mathrm{~A}^{\prime}$ \\
$\left(C_{s}\right)$ & 1741 & 1738 & $\mathrm{~A}^{\prime \prime}$ \\
& 1709 & 1710 & $\mathrm{~A}^{\prime}$ \\
$\mathrm{W}\left({ }^{12} \mathrm{CO}\right)\left({ }^{13} \mathrm{CO}\right)_{2}-\mathrm{Cs}_{56} \mathrm{Y}$ & 1866 & 1867 & $\mathrm{~A}^{\prime}$ \\
$\left(C_{s}\right)$ & 1718 & 1722 & $\mathrm{~A}^{\prime}$ \\
& 1699 & 1699 & $\mathrm{~A}^{\prime \prime}$ \\
$\mathrm{W}\left({ }^{13} \mathrm{CO}\right)_{3}-\mathrm{Cs}_{56} \mathrm{Y}$ & 1851 & 1850 & $\mathrm{~A}_{1}$ \\
$\left(C_{3 b}\right)$ & 1699 & 1699 & $\mathrm{E}$
\end{tabular}

${ }^{a}$ Best-fit Cotton-Kraihanzel CO force constants are $f_{\mathrm{r}}=12.95$ and $f_{\mathrm{rf}}=0.75 \mathrm{mdyne} / \AA$. RMS error in the eigenvalues is $1.744 \mathrm{~cm}^{-1}$.

Table IV. Observed and Calculated $\nu_{\mathrm{co}}$ Frequencies $\left(\mathrm{cm}^{-1}\right)$ of $C_{s}$ Distorted Trigonal-Pyramidal Mo $\left({ }^{12} \mathrm{CO}\right)_{m}\left({ }^{13} \mathrm{CO}\right)_{3-m}-\mathrm{Li}_{56} \mathrm{Y}$

\begin{tabular}{llll}
\multicolumn{1}{c}{ species } & obsd & calcd & assignment \\
\hline $\mathrm{Mo}\left({ }^{12} \mathrm{CO}\right)_{3}-\mathrm{Li}_{56} \mathrm{Y}$ & 1925 & 1925 & $\mathrm{~A}^{\prime}$ \\
$\left(C_{s}\right)$ & 1798 & 1795 & $\mathrm{~A}^{\prime \prime}$ \\
& 1760 & 1758 & $\mathrm{~A}^{\prime}$ \\
$\mathrm{Mo}\left({ }^{12} \mathrm{CO}\right)_{2}\left({ }^{13} \mathrm{CO}\right)-\mathrm{Li}_{56} \mathrm{Y}$ & 1925 & 1925 & $\mathrm{~A}^{\prime}$ \\
$\left(C_{s}\right)$ & 1798 & 1795 & $\mathrm{~A}^{\prime \prime}$ \\
$\mathrm{Mo}\left({ }^{12} \mathrm{CO}\right)_{2}\left({ }^{13} \mathrm{CO}\right)-\mathrm{Li}_{56} \mathrm{Y}$ & 1716 & 1718 & $\mathrm{~A}^{\prime}$ \\
$\left(C_{1}\right)$ & 1909 & 1907 & $\mathrm{~A}$ \\
& 1769 & 1772 & $\mathrm{~A}$ \\
$\mathrm{Mo}\left({ }^{12} \mathrm{CO}\right)\left({ }^{13} \mathrm{CO}\right)_{2}-\mathrm{Li}_{56} \mathrm{Y}$ & 1909 & 1758 & $\mathrm{~A}$ \\
$\left(C_{1}\right)$ & 1769 & 1777 & $\mathrm{~A}$ \\
& 1716 & 1718 & $\mathrm{~A}$ \\
$\mathrm{Mo}\left({ }^{12} \mathrm{CO}\right)\left({ }^{13} \mathrm{CO}\right)_{2}-\mathrm{Li}_{56} \mathrm{Y}$ & 1880 & 1882 & $\mathrm{~A}^{\prime}$ \\
$\left(C_{s}\right)$ & 1760 & 1758 & $\mathrm{~A}^{\prime}$ \\
$\mathrm{Mo}\left({ }^{13} \mathrm{CO}\right)_{3}-\mathrm{Li}_{56} \mathrm{Y}$ & 1755 & 1755 & $\mathrm{~A}^{\prime \prime}$ \\
$\left(C_{s}\right)$ & 1880 & 1882 & $\mathrm{~A}^{\prime}$ \\
& 1755 & 1755 & $\mathrm{~A}^{\prime \prime}$ \\
\hline
\end{tabular}

${ }^{\circ}$ Best-fit Cotton-Kraihanzel CO force constants are $f_{\mathrm{r}}=12.48, f_{\mathrm{r}}=$ 13.99, $f_{\mathrm{rr}}=1.11$, and $f_{\mathrm{rr}}=0.98 \mathrm{mdyne} / \AA$. RMS error in the eigenvalues is $2.055 \mathrm{~cm}^{-1}$

carbonyl, a result which unequivocally establishes the identity of the encapsulated and immobilized species to be the tricarbonylmetal (where $n=0-3$ ) having perfect $C_{3 v}$ (trigonal-pyramidal) symmetry: $\mathrm{W}\left({ }^{12} \mathrm{CO}\right)_{n}\left({ }^{13} \mathrm{CO}\right)_{3-n}-\mathrm{Cs}_{56} \mathrm{Y}$. The results of CottonKraihanzel frequency calculations for the four expected mixed isotopic molecules with $n=0-3$ are listed in Table III. The optimized Cotton-Kraihanzel bond-stretching $f_{\mathrm{r}}$ and stretchstretch interaction $f_{\text {rr }}$ force constants obtained in the above calculations are also listed in Table III.

(ii) The $C_{s} \mathrm{Mo}\left({ }^{12} \mathrm{CO}\right)_{n}\left({ }^{13} \mathrm{CO}\right)_{3-n}-\mathrm{Li}_{56} \mathrm{Y}$ System. The mid-IR spectrum of the proposed $C_{s}$ symmetry $\mathrm{Mo}\left({ }^{12} \mathrm{CO}\right)_{3}-\mathrm{Li}_{56} \mathrm{Y}$ intrazeolite tricarbonylmetal $(0)$ shows three strong absorption bands at 1925,1798 , and $1760 \mathrm{~cm}^{-1}$ for the $2 A^{\prime}+A^{\prime \prime} \nu C O$ stretching modes (Figure 6). The ${ }^{12} \mathrm{CO} /{ }^{13} \mathrm{CO}$ isotopic $\nu \mathrm{CO}$ vibrational patterns for the $\mathrm{Mo}\left({ }^{12} \mathrm{CO}\right)_{n}\left({ }^{13} \mathrm{CO}\right)_{3-n}-\mathrm{Li}_{56} \mathrm{Y}$ species for various ${ }^{13} \mathrm{CO}$ enrichments involve two triplets for the highest frequency $A^{\prime}(1)$ and the $A^{\prime \prime}$ and a doublet for the lowest frequency $A^{\prime}(2)$ $\nu \mathrm{CO}$ stretching fundamentals corresponding to the six possible isotopomers of the ${ }^{12} \mathrm{CO} /{ }^{13} \mathrm{CO}$ labeled intrazeolite subcarbonyl moiety summarized in Table IV. This result unequivocally establishes the identity of the species to be the tricarbonylmetal (where $n=0-3$ ) having $C_{s}$ symmetry: $\mathrm{Mo}\left({ }^{12} \mathrm{CO}\right)_{n}\left({ }^{13} \mathrm{CO}\right)_{3-n}$ $\mathrm{Li}_{56} \mathrm{Y}$. The observed and calculated $\nu \mathrm{CO}$ frequencies for the six expected isotopic molecules with $n=0-3$ are listed in Table IV together with the optimized Cotton-Kraihanzel bond-stretching $f_{r}, f_{r^{\prime}}$ and stretch-stretch interaction $f_{\pi r} f_{\pi^{\prime}}$ force constants obtained in the aforementioned calculations (Table $\mathrm{V}$ ).

The good agreement between the observed and calculated best fit $\nu \mathrm{CO}$ stretching modes for both species $\mathrm{W}\left({ }^{12} \mathrm{CO}\right)_{n}\left({ }^{13} \mathrm{CO}\right)_{3-n}$ $\mathrm{Cs}_{56} \mathrm{Y}$ and $\mathrm{Mo}\left({ }^{12} \mathrm{CO}\right)_{n}\left({ }^{13} \mathrm{CO}\right)_{3-n}-\mathrm{Li}_{56} \mathrm{Y}$ supports the chosen vibrational assignments (supplementary material Table IV) and provides additional evidence for the stoichiometry and geometry of the proposed $C_{3 v}$ or $C_{s}$ symmetry zeolite anchored tri-
Table V. Computed Cotton-Kraihanzel CO Bond Stretching Force Constants for $\mathrm{M}(\mathrm{CO})_{3}-\mathrm{M}^{\prime}{ }_{56} \mathrm{Y}$ (mdyne $\AA^{-1}$ )

\begin{tabular}{llrrr}
\hline & & $\mathrm{Cr}(\mathrm{CO})_{3}$ & $\mathrm{Mo}(\mathrm{CO})_{3}$ & $\mathrm{~W}(\mathrm{CO})_{3}$ \\
\hline \multirow{3}{*}{$\mathrm{Li}_{56} \mathrm{Y}$} & $f_{\mathrm{r}}$ & 13.01 & 13.02 & 13.15 \\
& $f_{\mathrm{r}^{\prime}}$ & 13.77 & 13.76 & 13.86 \\
& $f_{\mathrm{rr}}$ & 0.75 & 0.71 & 0.68 \\
$\mathrm{Na}_{56} \mathrm{Y}$ & $f_{\mathrm{r}}$ & 12.96 & 12.93 & 13.06 \\
& $f_{r^{\prime}}$ & 13.74 & 13.72 & 13.57 \\
& $f_{\mathrm{rr}}$ & 0.67 & 0.71 & 0.65 \\
$\mathrm{~K}_{56} \mathrm{Y}$ & $f_{\mathrm{r}}$ & 12.84 & 13.22 & 12.85 \\
& $f_{r^{\prime}}$ & 13.67 & 13.62 & 13.23 \\
& $f_{\text {rr }}$ & 0.70 & 0.69 & 0.65 \\
$\mathrm{Rb}_{56} \mathrm{Y}$ & $f_{\mathrm{r}}$ & 12.87 & 12.81 & 12.52 \\
& $f_{r^{\prime}}$ & 13.39 & 13.15 & 12.98 \\
& $f_{\text {rr }}$ & 0.82 & 0.76 & 0.75 \\
$\mathrm{Cs}_{56} \mathrm{Y}$ & $f_{\mathrm{r}}$ & 12.81 & 13.23 & 12.95 \\
& $f_{r^{\prime}}$ & 13.58 & & \\
& $f_{\mathrm{rr}}$ & 0.74 & 0.77 & 0.75 \\
\hline
\end{tabular}

carbonylmetal $(0)$ moieties, respectively. The question of whether the tricarbonylmetal( 0$)$ fragment is anchored in the $\alpha$-cage via extraframework cations or to a framework oxygen site will be addressed in detail later on in this paper.

(e) Details of the Anchoring Site of $\mathrm{M}(\mathrm{CO})_{3}-\mathrm{M}_{56}^{\prime} \mathrm{Y}$. (i) Internal Versus External Location of $\mathbf{M}(\mathbf{C O})_{3}-\mathbf{M}_{56}^{\prime} \mathbf{Y}$. Information arguing for or against the predominant region of attachment of the tricarbonylmetal fragment in the zeolite $Y$ crystals can be derived from reactivity studies with ligands that are designed to be either sufficiently small or too bulky to either gain free access to or be blocked from entry to the $\alpha$-cage through the 12-ring entrance window (7.8-8.0-A diameter). Size exclusion studies of this type employing large and small arenes and trialkylphosphines can nicely discern whether or not the $\mathrm{M}(\mathrm{CO})_{3}-\mathrm{M}_{56} \mathrm{Y}$ fragment is internally or externally confined ${ }^{1,2}$ The results of two series of representative experiments are presented in summary form below:

experiment 1 :

$$
\begin{gathered}
\mathrm{Cr}(\mathrm{CO})_{3}-\mathrm{Na}_{56} \mathrm{Y}+\mathrm{C}_{6} \mathrm{H}_{6} \rightarrow \mathrm{Cr}(\mathrm{CO})_{3}\left(\eta^{6}-\mathrm{C}_{6} \mathrm{H}_{6}\right)-\mathrm{Na}_{56} \mathrm{Y} \\
\mathrm{Cr}(\mathrm{CO})_{3}-\mathrm{Na}_{56} \mathrm{Y}+\mathrm{C}_{6} \mathrm{H}_{3}(\mathrm{t}-\mathrm{Bu})_{3} \rightarrow \text { no reaction }
\end{gathered}
$$

experiment 2 :

$$
\begin{gathered}
\mathrm{W}(\mathrm{CO})_{3}-\mathrm{Na}_{56} \mathrm{Y}+3 \mathrm{PMe}_{3} \rightarrow \mathrm{W}(\mathrm{CO})_{3}\left(\mathrm{PMe}_{3}\right)_{3}-\mathrm{Na}_{56} \mathrm{Y} \\
\mathrm{W}(\mathrm{CO})_{3}-\mathrm{Na}_{56} \mathrm{Y}+3 \mathrm{P}\left(\mathrm{C}_{6} \mathrm{H}_{11}\right)_{3} \rightarrow \text { no reaction }
\end{gathered}
$$

The experimental results clearly demonstrate that benzene and trimethylphosphine (supplementary material Table II, kinetic diameters 5.9 and $4.2 \AA$, respectively) can pass freely through the 12-ring entrance window to enter the supercage of zeolite $Y$ and cleanly react with the anchored $\mathrm{M}(\mathrm{CO})_{3}-\mathrm{M}_{56}^{\prime} \mathrm{Y}$ unit which resides there. In dramatic contrast the 1,3,5-tris(tert-butyl)benzene and tris(cyclohexyl)phosphine molecules (supplementary material Table II, kinetic diameters 9.8 and $10.9 \AA$, respectively) are effectively size-excluded from the $\alpha$-cage where the $\mathrm{M}(\mathrm{CO})_{3}$ $\mathrm{M}^{\prime}{ }_{56} \mathrm{Y}$ unit is located. One concludes from the results of experiments of the above type that the $\mathrm{M}(\mathrm{CO})_{3}-\mathrm{M}_{56}{ }_{56} \mathrm{Y}$ unit exists predominantly in the internal confines of the zeolite host lattice and not on its external surface.

(ii) Cation Effects on the $\mathrm{CO}$ Bond Stretching Force Constants of $\mathbf{M}(\mathbf{C O})_{3}-\mathbf{M}_{56} \mathbf{Y}$. An insight into the nature of the anchoring site of encapsulated $\mathrm{M}(\mathrm{CO})_{3}-\mathrm{M}_{56}^{\prime} \mathrm{Y}$ can be derived from the sensitivity of its carbonyl bond stretching force constants with respect to alterations in the ionic potential (charge/radius ratio) of the extraframework cations $\left(Z^{*} / r\right)$ and accompanying changes in the average electronegativity of the zeolite by using Sandersons $\left(S_{\text {int }}\right)$ scale. ${ }^{19}$

The collected results for $15 \mathrm{M}(\mathrm{CO})_{3}-\mathrm{M}_{56}{ }_{56} \mathrm{Y}$ samples encompassing $\mathrm{M}=\mathrm{Cr}, \mathrm{Mo}, \mathrm{W}$ and $\mathrm{M}^{\prime}=\mathrm{Li}, \mathrm{Na}, \mathrm{K}, \mathrm{Rb}, \mathrm{Cs}$ are laid

(19) Mortier, W. J.; Schoonheydt, R. A. Prog. Solid State Chem. 1985 16,1 , and references cited therein. 
out in Table $\mathrm{V}$ and supplementary material Table IV. As described earlier, in all but TWO samples, namely, $\mathrm{M}=\mathrm{Mo}, \mathrm{W}$ and $\mathrm{M}^{\prime}=\mathrm{Cs}$, the tricarbonylmetal moiety is anchored with $C_{s}$ distorted trigonal-pyramidal symmetry, whereas the two exceptions themselves exhibit $C_{3 v}$ regular trigonal-pyramidal symmetry.

Because of the presence of two $\left(C_{3 v}\right)$ or three $\left(C_{s}\right) \nu \mathrm{CO}$ stretching modes and the existence of different kinds of $\mathrm{CO}$ ligand in the $C_{s}$ symmetry fragment, a discussion of cation effects on the $\nu \mathrm{CO}$ vibrational spectrum of $\mathrm{M}(\mathrm{CO})_{3}-\mathrm{M}_{56}^{\prime} \mathrm{Y}$ is best couched in the terminology of $\mathrm{CO}$ bond stretching force constants rather than frequencies. To this end Cotton-Kraihanzel calculations were conducted on the complete set of 15 samples listed in supplementary material Table IV by using the observed frequencies of the available ${ }^{12} \mathrm{CO}$ and ${ }^{13} \mathrm{CO}$ labeled $\mathrm{M}\left({ }^{12} \mathrm{CO}\right)_{n}\left({ }^{13} \mathrm{CO}\right)_{3-n}-\mathrm{M}_{56}^{\prime} \mathrm{Y}$ species. The results are summarized in Table $\mathrm{V}$.

Three models can be seriously entertained for possible anchoring sites of $\alpha$-cage located $\mathrm{M}(\mathrm{CO})_{3}-\mathrm{M}_{56}^{\prime} \mathrm{Y}$ as illustrated below:
(A)<smiles>[Y10][C@@H](O)C(O)O</smiles>

(B)

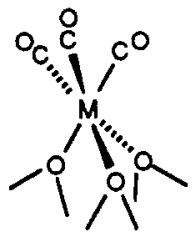

(C)<smiles>C1OC2O[N+]1O2</smiles>

Two of these candidates, $A$ and $C$, involve interaction of the $\mathrm{M}(\mathrm{CO})_{3}$ fragment with an extraframework cation, the former with direct binding of the metal center of the tricarbonyl moiety to the cation, the latter with indirect binding through the oxygen end of the carbonyls to the cation. Model A is anticipated to show cation effects on the $\mathrm{CO}$ bond stretching force constants, where the latter should decrease with decreasing ionic potential of the cation down the series $\mathrm{Li}^{+}$to $\mathrm{Cs}^{+}, 1,16$ By contrast model $\mathrm{C}$ is expected to show just the opposite effect. The third model B bypasses the extraframework cations altogether and considers the immobilization of the tricarbonylmetal moiety on the oxygens of the zeolite framework, over either a vacant six- or four-ring site devoid of an adjacent extraframework cation. In this circumstance the effect of extraframework cations is manifest in terms of alterations of framework oxygen charge density. As will be demonstrated in the following section, the far-IR spectra do not show any significant alteration in the cation translational vibrational frequencies upon formation of the $\mathrm{M}(\mathrm{CO})_{3}-\mathrm{M}_{56}{ }_{56} \mathrm{Y}$ moiety, arguing against model $A$ and $C$, and by a process of deductive elimination thereby favoring model B.

(iii) Adsorption Induced Far-IR Cation Translatory Mode Frequency Shifts for $\mathbf{M}(\mathrm{CO})_{3}-\mathbf{M}_{56} \mathbf{Y}$. As delineated earlier, adsorption-induced alterations of the frequencies of far-IR cation translational modes can signal the exact site of attachment of the adsorbent to the adsorbate. The great value of this anchoring site probe for zeolite $\mathrm{Y}$ was illustrated earlier with respect to $\mathrm{W}(\mathrm{C}$ $\mathrm{O}_{6}-\mathrm{Cs}_{56} \mathrm{Y}$ (Figure 5 and supplementary material). In this section we will exemplify the technique for the anchored subcarbonyl fragment $\mathrm{M}(\mathrm{CO})_{3}-\mathrm{M}_{56}^{\prime} \mathrm{Y}$. A representative series of in situ far-IR experiments is laid out in supplementary material Figure 5 for

$$
\mathrm{Cr}(\mathrm{CO})_{6}-\mathrm{Na}_{56} \mathrm{Y} \stackrel{-3 \mathrm{CO}}{\longrightarrow} \mathrm{Cr}(\mathrm{CO})_{3}-\mathrm{Na}_{56} \mathrm{Y} \stackrel{+3 \mathrm{CO}}{\longrightarrow} \mathrm{Cr}(\mathrm{CO})_{6}-\mathrm{Na}_{56} \mathrm{Y}
$$

In the virgin, defect removed, calcined, vacuum thermally dehydrated $\mathrm{Na}_{56} \mathrm{Y}$ the four occupied $\mathrm{Na}^{+}$cation sites are clearly resolved and as before are denoted II, I, I', III in order of decreasing frequency. ${ }^{20}$ The effect of adsorption of $\mathrm{Cr}(\mathrm{CO})_{6}$ is clearly seen by small (reproducible from run-to-run) blue shifts of about $4 \mathrm{~cm}^{-1}$ exclusively on the $\alpha$-cage located $\mathrm{Na}^{+}$cation labelled II (supplementary material Figure 5). This effect, as expected from our earlier discussion, is found to be most pronounced on the annealed samples and confirms our earlier proposal of $\mathrm{M}(\mathrm{CO})_{6}$ anchoring to $\alpha$-cage extraframework cations (Figures

(20) Ozin, G. A.; Godber, J.; Baker, M. D. J. Phys. Chem. 1989, 93, 2899.

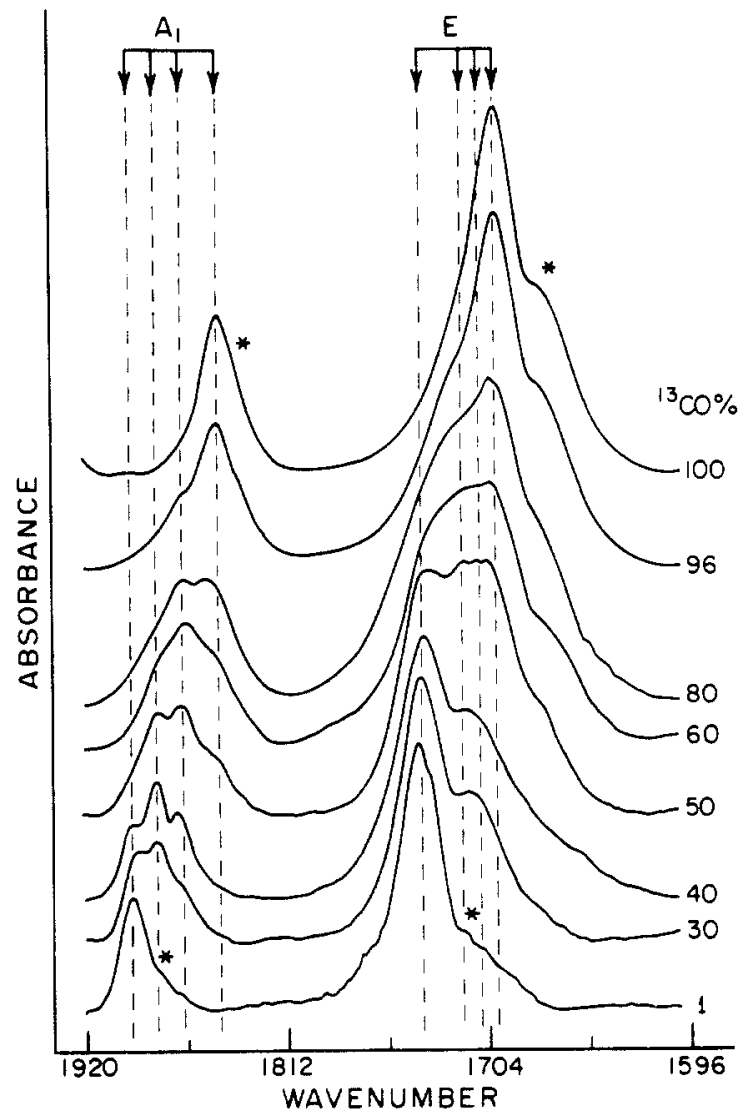

Figure 8. Mid-IR ${ }^{12} \mathrm{CO} /{ }^{13} \mathrm{CO}$ vibrational isotope spectral patterns of the $\mathrm{A}_{1}+\mathrm{E} \nu \mathrm{CO}$ modes of $\mathrm{W}\left({ }^{12} \mathrm{CO}\right)_{n}\left({ }^{13} \mathrm{CO}\right)_{3-n}-\mathrm{Cs}_{56} \mathrm{Y}$ (where $\left.n=0-3\right)$ with various levels of ${ }^{13} \mathrm{CO}$ enrichment. $A$ low concentration of a second trapping site of $\mathrm{W}\left({ }^{12} \mathrm{CO}\right)_{n}\left({ }^{13} \mathrm{CO}\right)_{3-n}-\mathrm{Cs}_{56} \mathrm{Y}$ is indicated by an asterisk.

1 and 2). Most pertinent to the subject matter of the anchoring site(s) for intrazeolite $\mathrm{M}(\mathrm{CO})_{3}-\mathrm{M}_{56}^{\prime} \mathrm{Y}$ is the observation of essentially no measurable far-IR adsorption induced frequency shifts for any of the $\mathrm{Na}^{+}$cation translational modes (supplementary material Figure 5). This observation brings forth compelling evidence that $\alpha$-cage encapsulated $\mathrm{M}(\mathrm{CO})_{3}-\mathrm{M}_{56}^{\prime} \mathrm{Y}$ is attached to an oxygen framework site rather than a cation site favoring model $B$ rather than its alternative models $A$ and $C$. This conclusion is consistent with the fact that $C_{s}$ symmetry is generally observed for $\mathrm{M}(\mathrm{CO})_{3}-\mathrm{M}^{\prime}{ }_{56} \mathrm{Y}$ (13 out of 15 samples), an observation which is not readily reconciled with either model $\mathrm{A}$ or $\mathrm{C}$. It is likely that an explanation of the interplay between $C_{s}$ and $C_{30}$ oxygen framework binding geometries for $\mathrm{M}(\mathrm{CO})_{3}-\mathrm{M}^{\prime}{ }_{56} \mathrm{Y}$ will have its origin in either a six versus a four-ring mode of attachment and/or the operation of a second-order Jahn-Teller effect, ${ }^{21}$ see later. Finally it is noteworthy that the $\nu \mathrm{CO}$ mid-IR spectra of $\mathrm{M}(\mathrm{CO})_{3} \mathrm{~L}_{3}$ complexes (where $\mathrm{L}=\mathrm{O}, \mathrm{N}$ class $\mathrm{A}$ donor ligands) including $\mathrm{M}(\mathrm{CO})_{3}\{18$-crown- 6$\}$ (this study) are very similar to those of our proposed model B oxygen framework binding site for $\mathrm{M}(\mathrm{CO})_{3}-\mathrm{M}_{56}^{\prime} \mathrm{Y}$, Table VI.

(iv) Cation Effects on the Optical/Electronic Properties of $\mathbf{M}(\mathbf{C O})_{3}-\mathbf{M}_{56}^{\prime} \mathbf{Y}$. The optical reflectance spectra of the 15 samples denoted $\mathrm{M}(\mathrm{CO})_{3}-\mathrm{M}_{56}^{\prime} \mathrm{Y}$ (where $\mathrm{M}=\mathrm{Cr}, \mathrm{Mo}, \mathrm{W} ; \mathrm{M}^{\prime}=\mathrm{Li}, \mathrm{Na}$, $\mathrm{K}, \mathrm{Rb}, \mathrm{Cs}$ ) for which the mid-IR spectra have been presented in Figures 6,7 , and 8 and supplementary material Table IV and discussed at some length, prove to be especially enlightening

Let us first consider the optical reflectance data obtained for defect removed, calcined, and vacuum thermally dehydrated "virgin" $M^{\prime}{ }_{56} Y$ zeolites (supplementary material Figure 6) and their respective freshly impregnated/annealed $\mathrm{M}(\mathrm{CO})_{6}-\mathrm{M}_{56}^{\prime} \mathrm{Y}$

(21) Albright, T. A.; Burdett, J. K.; Whangbo, M. H. Orbital Interactions in Chemistry; John Wiley: New York, 1985. Fischer, G. Vibronic Coupling, Academic Press: New York, 1984. Pearson, R. G. Symmetry Rules for Chemical Reactions: John Wiley: New York, 1976. Burdett, J. K. Molecular Shapes; John Wiley: New York, 1980. 


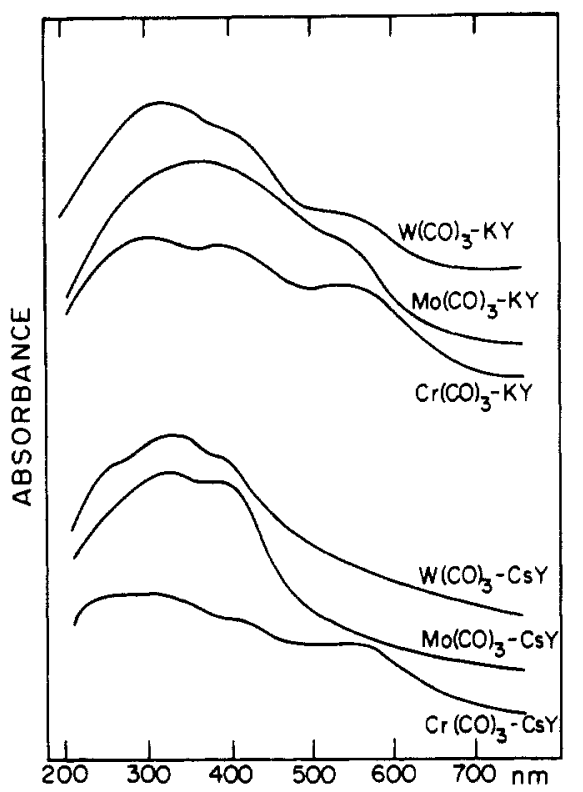

Figure 9. Optical reflectance data for $\mathrm{M}(\mathrm{CO})_{3}-\mathrm{M}_{56}{ }_{56} \mathrm{Y}$, where $\mathrm{M}=\mathrm{Cr}$, $\mathrm{Mo}, \mathrm{W} ; \mathrm{M}^{\prime}=\mathrm{K}, \mathrm{Cs}$, prepared from the samples shown in Figure 7 , supplementary material.

(supplementary material Figure 7) and vacuum thermally decarbonylated $\mathrm{M}(\mathrm{CO})_{3}-\mathrm{M}_{56}^{\prime} \mathrm{Y}$ (Figure 9) partners.

Inspection of the optical reflectance data for the virgin $\mathrm{M}_{56}^{\prime} \mathrm{Y}$ zeolites reveals the presence of UV bands with an absorption onset for all cations estimated to be in the range of about $500-520 \mathrm{~nm}$ (supplementary material Figure 6). Zeolite $Y$ can be considered to be an open framework aluminosilicate wide band-gap insulator. ${ }^{22}$ The valence band is principally composed of $\mathrm{O}(2 \mathrm{p} \pi)$ nonbonding orbitals, whilst the conduction band is built up from mainly $\mathrm{Si}^{\mathrm{IV}} \mathrm{O}$, $\left.\mathrm{A}\right|^{111} \mathrm{O}$ antibonding orbitals. ${ }^{22}$ It appears therefore that the threshold energy for band-gap absorption (500-520 nm), which incidentally can be considered to be of the LMCT type, is rather insensitive to the identity of the extraframework cation in the alkali metal group, even though the Sanderson electronegativity of the zeolite teaches us that the oxygen framework electron density increases on passing from $\operatorname{Li}_{56} Y$ to $\mathrm{Cs}_{56} Y$. ${ }^{19}$ This implies that the alkali metal simply behaves as an extraframework "spectator", while the VB and CB edges appear to shift in a parallel fashion with changing oxygen lattice charge density, maintaining the band gap $E_{g}$ essentially invariant to cation type in the series $\mathrm{M}_{56}^{\prime} \mathrm{Y}$. Alternatively, this effect might have its origin in terms of defect states (intrinsic or extrinsic, the latter introduced in the pretreatment steps) that exist within the band gap. Much more work will be required to pin down this interesting point.

On turning our attention briefly to the optical reflectance spectra of the freshly impregnated and thermally annealed $\left(50-80^{\circ} \mathrm{C}\right.$, see earlier) $\mathrm{M}(\mathrm{CO})_{6}-\mathrm{M}^{\prime}{ }_{56} \mathrm{Y}$ samples, one observes the characteristic intense, broad, and structured MLCT bands in the UV region expected for weakly perturbed low-spin, $d^{6}$ hexacarbonylmetal $(0)$ complexes. ${ }^{23}$ Representative spectra are depicted in supplementary material Figure 7 . Because of the difficulty of precisely pinpointing and satisfactorily assigning specific electronic transitions in this extensive $\mathrm{M}(\mathrm{CO})_{6}-\mathrm{M}_{56}^{\prime} \mathrm{Y}$ series it did not prove feasible to extract useful information on the metal and cation dependence of the MLCT energies. We now direct attention to the respective tricarbonylmetal $(0)$ zeolite $Y$ partners.

There now appears to be a general consensus between experiment and molecular orbital calculations that unperturbed $d^{6}$ $\mathrm{M}(\mathrm{CO})_{3}$ binary metal tricarbonyls of the group VIB metal triad exist with low-spin electronic configurations and a $C_{3 v}$ regular trigonal-pyramidal geometry, ${ }^{21}$ Clearly this simple picture of the pristine $\mathrm{M}(\mathrm{CO})_{3}$ fragments has to be rethought when they are anchored to a specific binding site in the zeolite $Y$ lattice. As

(22) Denks, V. P. Trudy Instituta Fiziki Akad. Nauk Estonskoi SSR $1984,55,14$
Table VI. ${ } \mathrm{CO}$ Stretching Frequencies $\left(\mathrm{cm}^{-1}\right)$ of Some Facial Tricarbonylmolybdenum $(0)$ Complexes Containing $\mathrm{N}$ - or O-Donor Ligands

\begin{tabular}{lllll}
\hline \multicolumn{1}{c}{ complex } & \multicolumn{2}{c}{$\nu \mathrm{CO}$} & \multicolumn{1}{c}{ solvent } & ref \\
\hline $\mathrm{Mo}(\mathrm{CO})_{3}$ (dien) & 1898 & 1758 & $\mathrm{CH}_{3} \mathrm{NO}_{2}$ & 41 \\
& 1887 & 1734 & mull & \\
$\mathrm{Mo}(\mathrm{CO})_{3}$ (diglyme) & 1896 & 1764 & $\mathrm{THF}$ & 42 \\
$\mathrm{Mo}(\mathrm{CO})_{3}(18$-crown-6) & 1876 & 1780 & $\mathrm{THF}$ & $\mathrm{a}$ \\
\hline
\end{tabular}

o Prepared by refluxing a solution of hexacarbonylmolybdenum( $(0)$ and 18 -crown-6 in THF for $12 \mathrm{~h}$ (this study).

Table VII. Lowest Energy MLCT Bands of $C_{5}$ Symmetry $\mathrm{M}(\mathrm{CO})_{3}-\mathrm{M}_{56}^{\prime} \mathrm{Y}$ (units $\mathrm{cm}^{-1}$ )

\begin{tabular}{lccc}
\hline & \multicolumn{3}{c}{ M } \\
\cline { 2 - 4 } $\mathrm{M}^{\prime}$ & $\mathrm{Cr}$ & $\mathrm{Mo}$ & $\mathrm{W}$ \\
\hline $\mathrm{Li}$ & 16670 & 17540 & 17390 \\
$\mathrm{Na}$ & 17390 & 17860 & 17543 \\
$\mathrm{~K}$ & 17700 & 18180 & 17860 \\
$\mathrm{Rb}$ & 17860 & 19050 & 18518 \\
$\mathrm{Cs}$ & 18350 & & \\
\hline
\end{tabular}

alluded to earlier, a pattern exists for the observed distribution of $C_{3 v}$ versus $C_{s}$ geometries for the $15 \mathrm{M}(\mathrm{CO})_{3}-\mathrm{M}^{\prime}{ }_{56} \mathrm{Y}$ samples, where the occurrence of the $C_{3 v}$ trigonal-pyramidal structure is unmistakably localized within the group of highest atomic number element samples, namely $\mathrm{M}=\mathrm{Mo}, \mathrm{W} ; \mathrm{M}^{\prime}=\mathrm{Cs}$. What is the origin of this phenomenon?

The optical reflectance spectra of the $\mathrm{M}(\mathrm{CO})_{3}-\mathrm{M}_{56}^{\prime} \mathrm{Y}$ samples corresponding to those of Figures 5-8, supplementary material Table IV and described earlier, display in a similar fashion to their parents $\mathrm{M}(\mathrm{CO})_{6}-\mathrm{M}_{56} \mathrm{Y}$ intense, broad, and structured UV absorptions which clearly also correspond to MLCT excitations most likely localized in the electronic manifold of the tricarbonylmetal $(0)$ fragment (Figure 9). However, there exists in 13 out of the 15 samples, an especially noteworthy and unique spectral feature, sufficiently red-shifted out of the UV-MLCT mass of absorptions into the visible range $(525-600 \mathrm{~nm})$ to be subjected to quantification with respect to the function of metal and cation type. Representative optical reflectance traces which illustrate the aforementioned characteristics are displayed in Figure 9. Particularly striking is the realization that ONLY those two samples devoid of the diagnostic $\mathrm{M}(\mathrm{CO})_{3}-\mathrm{M}^{\prime}{ }_{56} \mathrm{Y} 525-600-\mathrm{nm}$ visible band are precisely those which exist with a regular $C_{3 v}$ trigonal-pyramidal tricarbonylmetal $(0)$ geometry $(\mathrm{M}=\mathrm{Mo}, \mathrm{W}$; $\left.\mathrm{M}^{\prime}=\mathrm{Cs}\right)$. All 13 other $\mathrm{M}(\mathrm{CO})_{3}-\mathrm{M}_{56}^{\prime} \mathrm{Y}$ samples boast the tricarbonylmetal $(0)$ in its distorted $C_{s}$ pyramidal form (see earlier discussion). What is even more intriguing is that the energy corresponding to the $\lambda_{\max }$ of the unique $(525-600 \mathrm{~nm})$ feature shows some systematic trends with metal and cation type, namely

$$
\begin{aligned}
& E_{\mathrm{Cs}_{\mathrm{s}}}^{\mathrm{M}}>E_{\mathrm{Rb}}^{\mathrm{M}_{\mathrm{B}}}>E_{\mathrm{K}}^{\mathrm{M}_{\mathrm{K}}}>E_{\mathrm{Na}}^{\mathrm{M}_{\mathrm{Na}}}>E_{\mathrm{Li}}^{\mathrm{M}} \\
& E^{\mathrm{Mo}}{ }_{\mathrm{M}}>E_{\mathrm{M}}^{\mathrm{W}}>E^{\mathrm{Cr}_{\mathrm{M}}}
\end{aligned}
$$

These results are summarized in Table VII and displayed pictorially in supplementary material Figure 8 by using as the abscissa the reported Sanderson electronegativity of $\mathrm{M}_{56}^{\prime} \mathrm{Y}^{19}$ which is an informative guide to the effect of the extraframework cation on the oxygen framework electron density (we will return to this point later on). These are the clues that we need to begin our discussion of the likely origin of the extraframework cation and metal dependence of the juxtaposition of $C_{3 v}$ and $C_{s}$ structures for zeolite $\mathrm{Y}$ anchored tricarbonylmetal( $(0)$ fragments of the group VIB metals.

We commence this discussion by constructing the valence orbitals of a $C_{3 v}$ trigonal-pyramidal $\mathrm{M}(\mathrm{CO})_{3}$ fragment by using the procedure outlined by Burdett ${ }^{21}$ which involves the removal of three fac-CO ligands in an $O_{h}$ octahedral $\mathrm{M}(\mathrm{CO})_{6}$ complex (Figure 10). Three empty hybrid orbitals of symmetry $a_{1}+e$ are left behind which point toward the missing ligands. $A d^{6}$, low-spin $\left(\mathrm{t}_{2 \mathrm{~g}}{ }^{6}\right)$ 18-electron $O_{h}$ parent $\mathrm{M}(\mathrm{CO})_{6}$ complex gives birth to a d $\mathrm{d}^{6}$ low-spin $\left(\mathrm{a}^{2}{ }_{1} \mathrm{e}^{4}\right)$ 12-electron $C_{3 v} \mathrm{M}(\mathrm{CO})_{3}$ offspring in which 


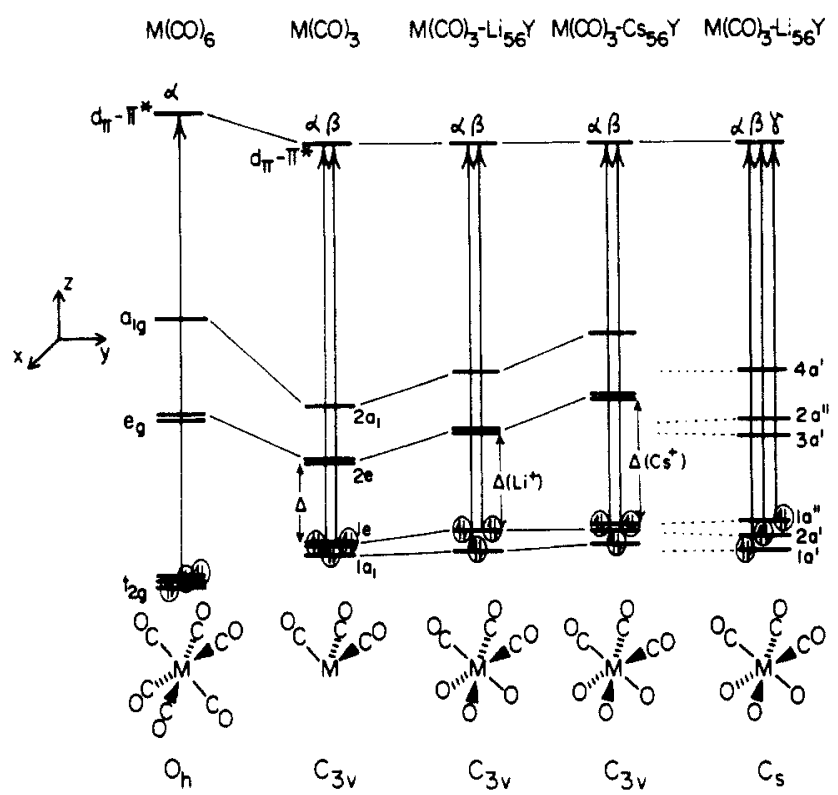

Figure 10. Fragment molecular orbital description of cation effects on the operation of a $C_{30}$ to $C_{s}$ SOJT distortion for $\mathrm{M}(\mathrm{CO})_{3}-\mathrm{M}^{\prime}{ }_{56} \mathrm{Y}$.

the latter also possesses three filled valence orbitals of symmetry $a_{1}+e$ which closely correspond to the $t_{2 g}$ set of the original octahedron (Figure 10). As the removal of three $\pi$-acceptor $\mathrm{CO}$ ligands effectively depletes the molecule of some $\mathrm{M}-\mathrm{CO} \pi$ backbonding, then the three members of the $t_{2 g}$ set will rise in energy on traversing to their $a_{1}+e$ counterparts in $M(C O)_{3}$ concomitant with the decrease in energy of the high-lying $M$ $(\mathrm{d} \pi)-\mathrm{CO}\left(2 \pi^{*}\right)$ set. The e set is stabilized considerably on passing to $\mathrm{M}(\mathrm{CO})_{3}$ because one-half of the $\sigma$-antibonding contribution from the $\mathrm{CO} 5 \sigma$ lone pairs to the metal is lost. These preliminary ideas are couched in the left-hand side orbital diagrams of Figure 10.

Because model $\mathrm{B}$, in which the $\mathrm{M}(\mathrm{CO})_{3}$ moiety is attached to the framework via lattice oxygens, is most consistent with the data presented so far let us now proceed to expand upon Figure 10 by including the effect of bringing three oxygen ligands in a $C_{3 v}$ arrangement up to the $C_{3 v} \mathrm{M}(\mathrm{CO})_{3}$ fragment to form the postulated $C_{3 v}$ six-coordinate representation of anchoring site B. As a framework oxygen atom contains both $2 \mathrm{p} \sigma$ and $2 \mathrm{p} \pi$ donor orbitals lying at lower energy than the filled valence $a_{1}+$ e set of the $\mathrm{M}(\mathrm{CO})_{3}$ fragment, then one can visualize that the major effect of attachment of $\mathrm{M}(\mathrm{CO})_{3}$ to a zeolite six-ring oxygen framework site will be to cause the energy of the empty valence $a_{1}+\mathrm{e} \sigma$-set of orbitals to rise with a parallel but lesser effect on the filled valence $a_{1}+e \pi$-set with minimal perturbation of the high-lying $\mathrm{M}(\mathrm{d} \pi)-\mathrm{CO}\left(2 \pi^{*}\right)$ group (Figure 10).

An important point to note from the above discussion is that the original HOMO-LUMO energy gap of the naked $\mathrm{M}(\mathrm{CO})_{3}$ fragment denoted $\Delta$ must increase on passing to $\mathrm{M}(\mathrm{CO})_{3}-\mathrm{M}_{56}^{\prime} \mathrm{Y}$, denoted $\Delta\left(\mathrm{M}^{\prime+}\right)$. The Sanderson electronegativities reported for the alkali metal $\mathrm{M}^{\prime}{ }_{36} \mathrm{Y}$ zeolites show that the charge-density on the framework oxygens increases on passing from $\mathrm{Li}^{+}$to $\mathrm{Cs}^{+} .19$ This phenomenon is accounted for in the $\mathrm{M}(\mathrm{CO})_{3}-\mathrm{M}_{56}^{\prime} \mathrm{Y}$ orbital energy level scheme by the anticipated increase in $\Delta\left(\mathrm{M}^{\prime+}\right)$ on passing from $\mathrm{Li}_{56} \mathrm{Y}$ to $\mathrm{Cs}_{56} \mathrm{Y}$ (Figure 10).

(v) Evidence for the Operation of a $C_{3 v}$ Second-Order JahnTeller (SOJT) Distortion for the Framework Oxygen Anchored Tricarbonylmetal(0) Fragment. It is with this starting electronic architecture for $\mathrm{M}(\mathrm{CO})_{3}-\mathrm{M}_{56}^{\prime} \mathrm{Y}$ that one can begin to discuss the metal and cation dependence of the optical and structural properties of the immobilized tricarbonylmetal( 0 ) fragment in zeolite $Y$. Probably the most important clue in the puzzle is the realization that the HOMO-LUMO energy gap for $C_{3 v} \mathrm{M}(\mathrm{CO})_{3}-$ $\mathrm{M}_{56}^{\prime} \mathrm{Y}$ is expected to be "greatest" for the highest atomic number metal and cation types (effective nuclear charge and framework oxygen electron density considerations respectively, as described above). This is precisely where the $C_{30}$ to $C_{s}$ distortion arises, namely $\mathrm{Mo}(\mathrm{CO})_{3}-\mathrm{Cs}_{56} \mathrm{Y}$ and $\mathrm{W}(\mathrm{CO})_{3}-\mathrm{Cs}_{56} \mathrm{Y}$ are uniquely $C_{3 v}$, whereas the remainder are $C_{s}$ !

On the basis of the above, the first thought that comes to mind at this point is that a first-order Jahn-Teller effect (FOJT) is operative. ${ }^{21}$ However, according to our orbital/electronic description of zeolite $\mathrm{Y}$ anchored $\mathrm{M}(\mathrm{CO})_{3}-\mathrm{M}^{\prime}{ }_{56} \mathrm{Y}$, the system is almost certainly $\mathrm{d}^{6}$ low-spin $\left(\mathrm{a}_{1}{ }^{2} \mathrm{e}^{4}\right)$ with an orbitally nondegenerate ${ }^{1} A_{1}$ ground state. Therefore the system is expected to be rigorously FOJT stable!

However, we cannot overlook the possible existence of a structural distortion arising from a second-order Jahn-Teller (SOJT) effect. ${ }^{21}$

It is our contention that it is the coupling between the closely spaced HOMO le and LUMO $2 \mathrm{e}$ states of $C_{3 v} \mathrm{M}(\mathrm{CO})_{3}-\mathrm{M}^{\prime}{ }_{56} \mathrm{Y}$ (Figure 10) through a degenerate e-type vibrational motion (e $X \mathrm{e}=\mathrm{a}_{1}+\mathrm{a}_{2}+\mathrm{e}$ ) that leads to the observed SOJT distortion to the lower symmetry $C_{s}$ species. This will be favored ONLY for those circumstances that boast a small HOMO-LUMO energy gap, ${ }^{21}$ namely low a tomic number elements for both $\mathbf{M}$ and $\mathbf{M}^{\prime}$ On this basis it is easy to appreciate why it is, that in the $3 \times 5$ matrix of $15 \mathrm{M}(\mathrm{CO})_{3}-\mathrm{M}_{56}^{\prime} \mathrm{Y}$ samples, it is ONLY the $\mathrm{M}=\mathrm{Mo}$, $\mathrm{W}$ and $\mathrm{M}^{\prime}=\mathrm{Cs}^{+}$systems that exist with the regular $C_{30}$ trigonal-pyramidal geometry; the rest undergo a SOJT distortion and settle down in the reduced symmetry $C_{s}$ distorted trigonal-pyramidal form.

Two other potentially competing effects deserve brief mention with respect to the origin of the observed distortion. The first involves molecule symmetry reduction by anchoring $\mathrm{M}(\mathrm{CO})_{3}$ to a zeolite four-ring rather than a six-ring oxygen framework site without the need to invoke a SOJT. The second considers a system far removed from a degenerate FOJT description but having states in accidental degeneracy. ${ }^{21}$ Although the EXAFS data for $C_{s}$ distorted trigonal-pyramidal $\mathrm{Mo}(\mathrm{CO})_{3}-\mathrm{Rb}_{56} \mathrm{Y}$ suggests that anchoring of $\mathrm{Mo}(\mathrm{CO})_{3}$ to two framework oxygens (either of a four-ring or six-ring) is a possibility (see later), it is our contention that there exists no compelling reason why an empty four-ring would prefer to bind only $\mathrm{M}=\mathrm{Mo}, \mathrm{W} ; \mathrm{M}^{\prime}=\mathrm{Cs}^{+}$samples. Furthermore, it is deemed unlikely in view of the currently accepted electronic structure for $\mathrm{M}(\mathrm{CO})_{3}$ shown in Figure 10 that accidental electronic degeneracies can account for the predominance of the distortion for the heavier central metals and extraframework cations.

(vi) Optical Assignments for $\mathbf{M}(\mathbf{C O})_{3}-\mathbf{M}_{56} \mathbf{Y}$. Having discussed possible models for the origin and occurrence of the $C_{3 v}$ to $C_{s}$ structural distortion amongst the various intercombinations of $\mathrm{M}$ and $\mathrm{M}^{\prime}$ in the $15 \mathrm{M}(\mathrm{CO})_{3}-\mathrm{M}_{56}^{\prime} \mathrm{Y}$ samples, let us now address some pertinent questions concerning (i) the assignment of the low-energy electronic transition diagnostic of the distorted $C_{s}$ isomer, (ii) the cause of the observed metal and cation dependence of this diagnostic spectral feature, and (iii) how these assignments and trends pertain to the choice of $A, B$, or $C$ as models for the site of attachment of $\mathrm{M}(\mathrm{CO})_{3}-\mathrm{M}_{56}^{\prime} \mathrm{Y}$.

This discussion begins with a straightforward extension of the electronic energy level scheme of $C_{3 v} \mathrm{M}(\mathrm{CO})_{3}-\mathrm{M}_{56}{ }_{56} \mathrm{Y}$ to account for the effect of a $C_{s}$ distortion (Figure 10). All orbital degeneracies are removed on lowering the $C_{3 v}$ symmetry to $C_{s}$ which results in a splitting of the crucial HOMO le level (Figure 10). Therefore, MLCT excitations originating in this le level $\left(C_{30}\right)$ and terminating in the $\mathrm{M}(\mathrm{d} \pi)-\mathrm{CO}\left(2 \pi^{*}\right)$ LUMO set of orbitals $\left(C_{3 v}\right)$ denoted the $\beta$-band in Figure 10 can now split into two sets, each originating from the $1 a^{\prime}+1 a^{\prime \prime}$ nondegenerate components $\left(C_{s}\right)$ of the original le degenerate level $\left(C_{3 v}\right)$ and again terminating in the $\mathrm{M}(\mathrm{d} \pi)-\mathrm{CO}\left(2 \pi^{*}\right)$ group of orbitals. It is the lowest energy of these two component bands (denoted $\gamma$ in Figure 10) that we propose is best associated with the low-energy 525-600-nm optical absorption, unique to the $C_{s} \mathrm{M}(\mathrm{CO})_{3}-\mathrm{M}_{56}^{\prime} \mathrm{Y}$ samples (Figure 9). Clearly $\beta$ and $\gamma$ become degenerate in the $C_{3 v} \mathrm{M}(\mathrm{CO})_{3}-\mathrm{M}_{56}^{\prime} \mathrm{Y}$ samples, which as described earlier occurs only for $\mathrm{M}=\mathrm{Mo}, \mathrm{W}$; $\mathbf{M}^{\prime}=\mathrm{Cs}$ in Figure 9 . What remains to be accounted for is the striking cation dependence of the $\gamma$-band as described earlier (supplementary material Figure 8, Table VII). Recall that the three contenders for the mode of attachment of the $\mathrm{M}(\mathrm{CO})_{3}$ 
fragment to the zeolite, described earlier, were models A, B, and $C$, where by a process of elimination the experimental data up to this point strongly favored $\mathrm{B}$ involving binding of $\mathrm{M}(\mathrm{CO})_{3}$ to a zeolite six-ring oxygen framework site. Below we consider the effect of the $\mathrm{A}, \mathrm{B}$, and $\mathrm{C}$ anchoring modes on the HOMO-LUMO $\gamma$-band energy involving states best described as $M(d \pi)$ and $\mathrm{M}(\mathrm{d} \pi)-\mathrm{CO}\left(2 \pi^{*}\right)$, respectively.

(A)

(B)

(c)

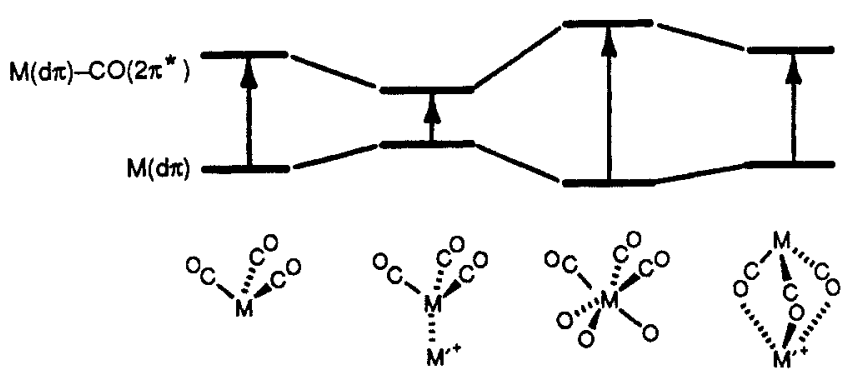

In the case of model $\mathrm{A}$, direct binding of the metal $\mathrm{M}$ to the cation $\mathrm{M}^{\prime+}$ is expected to cause a decrease in $\mathrm{M}-\mathrm{CO} \pi^{*}$-backbonding of $\mathrm{M}(\mathrm{CO})_{3}$ which should cause the $\gamma$-band to progressively blue shift on passing from $\mathrm{Li}^{+}$to $\mathrm{Cs}^{+}$which is what is observed in practice (supplementary material Figure 8, Table VII). Interaction model $\mathrm{C}$ involving cation binding to the oxygen end of the carbonyl ligand is expected to weaken the $\mathrm{CO} \pi$-bond itself which is expected to have little effect on the $\gamma$-band energy with changing ionic potential of the cation, thereby arguing against model $\mathrm{C}$ as a candidate. Finally oxygen framework binding model $B$ involves increasing $2 \mathrm{p} \sigma$ and $2 \mathrm{p} \pi$ electron density on the oxygen ligands on passing from $\mathrm{Li}^{+}$to $\mathrm{Cs}^{+}$(i.e., decreasing Sanderson electronegativity of the zeolite ${ }^{19}$ ) which should cause an increase in $\mathrm{M}-\mathrm{CO} \pi^{*}$-backbonding and a monotonic blue shift of the $\gamma$-band with increasing alkali metal cation mass. This is the behavior observed experimentally (supplementary material Figure 8 , Table VII). Therefore one concludes that the optical data alone cannot unambiguously distinguish anchoring model $\mathrm{A}$ from $\mathrm{B}$ as the most likely contender for the site of attachment of $\mathrm{M}(\mathrm{CO})_{3}$ to $\mathrm{M}^{\prime}{ }_{56} \mathrm{Y}$. However, when taken in conjunction with the far-IR adsorption induced cation translatory mode frequency shifts (described earlier) the optical reflectance results can be considered to provide additional support for oxygen framework attachment of $\mathrm{M}(\mathrm{CO})_{3}$ in zeolite $\mathrm{Y}$.

(vii) EXAFS Study of $8\left\{\mathbf{M o}(\mathrm{CO})_{3}\right\}-\mathbf{R b}_{56} Y$. EXAFS structure determination was performed with the representative sample $8\left\{\mathrm{Mo}(\mathrm{CO})_{3}\right\}-\mathrm{Rb}_{56} \mathrm{Y}$ in order to establish the metal-to-carbonyl stoichiometry and the mode of attachment to the zeolite framework. From the Fourier transformed Mo-edge data of this sample (supplementary material Figure 9a) it is immediately apparent that the carbonyl ligands are still intact. Both peaks, representing the Mo- $\underline{C}$ and Mo-C $\underline{O}$ contribution of the carbonyl, are reduced in their magnitude, indicating a loss of $\mathrm{CO}$ ligands with respect to sample Mo6Rb (supplementary material Figure 2). An overlay of the imaginary parts of the Fourier transformations of sample Mo6Rb and Mo3Rb in supplementary material Figure 9b shows a strong bond contraction of $\mathrm{Mo}-\underline{\mathrm{C}}$ and $\mathrm{Mo}-\mathrm{CQ}$ of $\mathrm{Mo} 3 \mathrm{Rb}$. For a quantitative analysis of these observations we first consider the oxygen component of the carbonyl ligand. A back transformation of this part and fit with the $\mathrm{Mo}(\mathrm{CO})_{6}$ reference results in an excellent fit shown in supplementary material Figure 9d. As listed in Table II, a short Mo-C-O bond length of $3.06 \AA$ is found in comparison to $3.21 \AA$ in $\mathrm{Mo}(\mathrm{CO})_{6}-\mathrm{Rb}_{56} \mathrm{Y}$. For the determinations of the number of carbonyl ligands attached to molybdenum, the data were fit with sample $\mathrm{Mo}(\mathrm{CO})_{6}-\mathrm{Rb}_{56} \mathrm{Y}$ as a $\mathrm{Mo}(\mathrm{CO})_{6}$ reference resulting in $N=3.4$ (using crystalline $\mathrm{Mo}(\mathrm{CO})_{6}, N=4.3$ ). This agrees well with the stoichiometry $\mathrm{Mo}(\mathrm{CO})_{3}$ derived from the other spectroscopic studies for this fragment.

Close inspection of the back transformed first shell of sample $\mathrm{Mo} 3 \mathrm{Rb}$ shows that a second (or more) contribution is convoluted with the carbon part of the metal carbonyl. This can be seen in a strong reduction of the third oscillation (supplementary material Figure 9c). Fit attempts including two contributions to this peak were never quite satisfying, but the results indicate that ca. three carbon atoms are bonded to the molybdenum at a distance of 1.93 $\AA$ and that about two additional oxygens are present at ca. 1.82 $\AA$. The next step was to inspect the rubidium edge data of this sample. The Fourier transformed data of $\mathrm{RbMo} 3$ are depicted in supplementary material Figure 10a, and the imaginary part is compared to the precursor sample $\mathrm{RbY}$ in supplementary material Figure $10 \mathrm{~b}$. The latter shows clearly that no significant differences can be observed between both data sets below $2.5 \AA$, the range where additional oxygen coordination at the molybdenum edge was observed. Hence, a rubidium-molybdenum interaction can clearly be excluded, since such an interaction should show up at the same distance in both $\mathrm{Rb}$ and Mo edge data. Some minor differences between $\mathrm{RbY}$ and $\mathrm{Mo} 3 \mathrm{Rb}$ are visible between 2.5 and $4 \AA$. Subtraction of the RbMo3 file from $\mathrm{RbY}$ resulted in a difference file which could be fitted with a $\mathrm{Rb}-\mathrm{Si} / \mathrm{Al}$ contribution. The result indicates that in $\mathrm{RbY}$ the rubidium ions interact with 0.5 more $\mathrm{Si} / \mathrm{Al}$ ions than in the $\mathrm{RbMo} 3$ sample.

In conclusion, these EXAFS data confirm the $\mathrm{Mo}(\mathrm{CO})$, stoichiometry of the sample $\mathrm{Mo}(\mathrm{CO})_{3}-\mathrm{Rb}_{56} \mathrm{Y}$. Second, the data eliminate the possibility of a direct attachment of the molybdenum carbonyl fragment to an extraframework rubidium ion as shown in model $\mathrm{A}$. Model $\mathrm{C}$ can be excluded, since one would expect an increase of the coordination number for $\mathrm{Rb}-\mathrm{O}$ from 3 to $4-6$, and most likely a second $\mathrm{Rb}-\mathrm{O}$ bond distance, both of which were not observed. Furthermore, model $\mathrm{C}$ would predict a relative elongation of the Mo- $\mathrm{CO}$ bond with respect to an uncoordinated $\mathrm{Mo}(\mathrm{CO})_{3}$ fragment, while the data show a shrinkage from 3.21 to $3.06 \AA$. Also, the bond angle of $\mathrm{Mo}-\mathrm{C}-\mathrm{O}$ could be expected to deviate from $180^{\circ}$ and should result in an apparent coordination number smaller than three, which was not observed. Finally, the Mo edge data provide a strong indication for an additional interaction of molybdenum with a light element such as oxygen, thus supporting model B. The oxygen coordination number of the fragment is not well defined. However, it appears to be closest to two. This suggests either predominant coordination of $\mathrm{Mo}(\mathrm{CO})_{3}$ to two of the three framework oxygens of a six-ring site or binding to two of the four framework oxygens of a four-ring site, which is in line with the $C_{s}$ distortion of this particular tricarbonyl fragment as described earlier. Note that the formation of a $\left[\mathrm{Mo}(\mathrm{CO})_{4}\right]_{2}$ dimer, as suggested by Howe et al..$^{24}$ for the decomposition product at $100^{\circ} \mathrm{C}$ in $\mathrm{NaY}$, is unlikely in view of these EXAFS results.

It is interesting that recently reported EXAFS data for the isoelectronic 12-electron intrazeolite half-sandwich complex $\{\mathrm{CpFe}\}^{+}-\mathrm{Na}_{56} \mathrm{Y}$ demonstrates that this moiety is also encapsulated in the $\alpha$-cage of zeolite $\mathrm{Y}$ and attached to an oxygen framework six- or four-ring site. ${ }^{25}$

From the collective results of this study and the EXAFS investigation, one can deduce that $\mathrm{M}(\mathrm{CO})_{3}-\mathrm{M}_{56}^{\prime} \mathrm{Y}$ samples are most satisfactorily described in terms of anchoring site model $\mathrm{B}$.

(viii) EXAFS Study of the Thermal Decomposition of 8/Mo$\left.(\mathrm{CO})_{3}\right\}-\mathbf{R b}_{56} \mathbf{Y}$. When the $8\left\{\mathrm{Mo}(\mathrm{CO})_{3}\right\}-\mathrm{Rb}_{56} \mathrm{Y}$ sample is further heated to $250^{\circ} \mathrm{C}$ in vacuum the decarbonylation is complete, as demonstrated by the absence of $\mathrm{CO}$ ligands in the IR spectra. The Fourier transformed data of the Mo edge of this sample (supplementary material Figure 11a) supports the total decomposition: no peak at ca. 2.6 $\AA$ (uncorrected for phase-shift) from the CQ ligands is detected. The only visible contribution occurs at ca. $1.8 \AA$ (uncorrected) with a surprisingly small magnitude (note scale of figure, $1 / 10$ of sample Mo6Rb). Fitting with $\mathrm{MoO}_{4}{ }^{2-}$ results in a Mo-C or Mo-O coordination with an extremely small average coordination number of 0.6 and a bond length of 2.08

(23) Geoffroy, G. L.; Wrighton, M. S. Organometallic Photochemistry; Academic Press: New York, 1979. Lever, A. B. P. Inorganic Electronic Spectroscopy; Elsevier: Amsterdam, 1984. 2887.

Yong, Y. S.; Howe, R. F. J. Chem. Soc., Faraday Trans. 1 1986, 82,

(25) Yong, Y. S.; Howe, R. F.; Hughes, A. E.; Jaeser, H.; Sexton, B. A. J. Phys, Chem. 1987, 91, 6331 . 
$\AA$. No other scattering is detectable, in particular, no Mo-Mo peaks from molybdenum metal particles are observed. This finding can only be interpreted with the formation of isolated molybdenum atoms which are statistically distributed in the zeolite lattice. The position of the absorption edge itself is identical with Mo foil and clearly indicates that no oxidation has occurred (in comparison, $\mathrm{Mo}^{4+}$ is shifted $+4 \mathrm{eV}$ and $\mathrm{Mo}^{6+}$ is shifted $+6 \mathrm{eV}$ higher relative to $\mathrm{Mo}^{\circ}$ ). The presence of zerovalent Mo atoms as a decomposition product from $\mathrm{Mo}(\mathrm{CO})_{6}$ in zeolite $\mathrm{NaY}$ was assumed by Howe et al. from XPS studies. ${ }^{25}$ This is in contrast to HY zeolites, where oxidation of Mo occurs. ${ }^{26}$

An overlay of Rb-edge data of samples RbY and RbMoM in supplementary material Figure $11 \mathrm{~b}$ shows only slightly reduced magnitudes for $\mathrm{Rb}-\mathrm{O}$ and $\mathrm{Rb}-\mathrm{Si}$ in the Mo-containing sample $\mathrm{RbMoM}$ (see Table II) which establishes that no interaction between $\mathrm{Rb}$ and the newly formed Mo atoms has occurred. In case of the above $\mathrm{Rb}-\mathrm{Mo}(0)$ sample, diffusion of the molybdenum atoms from the supercage into smaller cages may be prevented due to blocking of the six-ring apertures by the large rubidium cations. More recently Howe et al. ${ }^{15}$ have used EXAFS structure analysis to study the $200^{\circ} \mathrm{C}$ thermal decomposition product of $16\left\{\mathrm{Mo}(\mathrm{CO})_{6}\right\}-\mathrm{Na}_{56} \mathrm{Y}$, which contains $2 \mathrm{Mo}(\mathrm{CO})_{6} / \alpha$-cage. It is fascinating to note that these samples are proposed to yield uniformly dispersed $\mathrm{Mo}_{2}$ clusters in the $\alpha$-cage of $\mathrm{Na}_{56} \mathrm{Y}$, while our $8\left\{\mathrm{Mo}(\mathrm{CO})_{6}\right\}-\mathrm{Rb}_{56} \mathrm{Y}$, with $1 \mathrm{Mo}(\mathrm{CO})_{6} / \alpha$-cage, yields exclusively $M o$ atoms in $\mathrm{Rb}_{56} \mathrm{Y}$.

(f) Reactivity Studies of $\mathbf{M}(\mathrm{CO})_{3}-\mathbf{M}_{56} \mathbf{Y}$. It is found, for example, that $\mathrm{M}(\mathrm{CO})_{3}-\mathrm{Na}_{56} \mathrm{Y}$ reacts with $\mathrm{CO}$ at room temperature to yield $\mathrm{M}(\mathrm{CO})_{6}-\mathrm{Na}_{56} \mathrm{Y}$ in its annealed form. The highest recarbonylation yield of the tricarbonylmetal fragment back to its hexacarbonylmetal parent occurs for $\mathrm{Mo}(\mathrm{CO})_{3}$ encapsulated in $\mathrm{Li}_{56} \mathrm{Y}$. The unaccounted for material most likely exists as intrazeolite metal clusters. ${ }^{15}$

As mentioned earlier $\mathrm{M}(\mathrm{CO})_{3}-\mathrm{Na}_{56} \mathrm{Y}$ reacts with benzene to yield $\mathrm{M}(\mathrm{CO})_{3}\left(\eta^{6}-\mathrm{C}_{6} \mathrm{H}_{6}\right)-\mathrm{Na}_{56} \mathrm{Y}$. The intrazeolite $\eta^{6}$-benzenetricarbonylmetal $(0)$ complex can also be formed by the thermal decarbonylation of $\mathrm{M}(\mathrm{CO})_{6}-\mathrm{Na}_{56} \mathrm{Y}$ in the presence of $\alpha$-cage adsorbed benzene or by direct vapor phase impregnation of the organometallic complex into $\mathrm{Na}_{56} \mathrm{Y}$. In all three approaches the mid-IR spectrum of the product $\mathrm{M}(\mathrm{CO})_{3}\left(\eta^{6}-\mathrm{C}_{6} \mathrm{H}_{6}\right)-\mathrm{Na}_{56} \mathrm{Y}$ exhibits three strong $\nu \mathrm{CO}$ stretching modes for $\mathrm{M}=\mathrm{Cr}$, Mo and two for $\mathrm{M}=\mathrm{W}$ indicating $C_{s}$ and $C_{3 v}$ symmetry for the anchored $\mathrm{Cr}$, Mo, and $\mathrm{W}$ complexes, respectively. The results for $\mathrm{M}=\mathrm{Cr}$, $\mathrm{Mo}, \mathrm{W}$ in $\mathrm{Na}_{56} \mathrm{Y}$ are listed in supplementary material Table $\mathrm{V}$. Two possible anchoring geometries can be considered reasonable for intrazeolite $\mathrm{M}(\mathrm{CO})_{3}\left(\eta^{6}-\mathrm{C}_{6} \mathrm{H}_{6}\right)-\mathrm{Na}_{56} \mathrm{Y}$, one involving extraframework cation interaction with the $\pi$-electron density of the arene ring, denoted as site 1 , and the other with the oxygen-end of the carbonyl ligands, denoted site as 2 , as illustrated below.
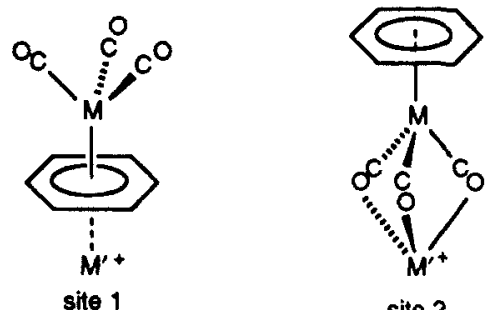

In all cases the $\nu \mathrm{CO}$ stretching frequencies are shifted toward lower energies by about $60 \mathrm{~cm}^{-1}$ compared to the respective solution phase values. This suggests that the intrazeolite $M$ $(\mathrm{CO})_{3}\left(\eta^{6}-\mathrm{C}_{6} \mathrm{H}_{6}\right)-\mathrm{Na}_{56} \mathrm{Y}$ complex is anchored to an extraframework supercage cation site predominantly in the site 2 configuration.

In contrast to the situation in solution where molecules can tumble freely, intrazeolite $\mathrm{M}(\mathrm{CO})_{3}\left(\eta^{6}-\mathrm{C}_{6} \mathrm{H}_{6}\right)-\mathrm{Na}_{56} \mathrm{Y}$ is rigidly bonded to the extraframework cations, causing its symmetry to

(26) Komatsu, T.; Namba, S.; Yashima, T.; Domen, K.; Onishi, T. J. Mol Catal. 1985, 33, 345 be lowered from $C_{3 v}$ to $C_{s}$ (site 2) for $\mathrm{Cr}$ and Mo but not for W (supplementary material Table V). This distortion could originate from either a preferential interaction of the cation with two carbonyl ligands (possibly a SOJT effect) or from the effect of binding of the carbonyl ligands with a cation residing over a four-ring lattice site.

As described earlier $\mathrm{M}(\mathrm{CO})_{3}-\mathrm{M}_{56}{ }_{56} \mathrm{Y}$ reacts with 1,3,5-cycloheptatriene to cleanly yield intrazeolite $\mathrm{M}(\mathrm{CO})_{3}\left(\eta^{6}-\mathrm{C}_{7} \mathrm{H}_{8}\right)-\mathrm{M}_{56}^{\prime} \mathrm{Y}$. For $\mathrm{M}=\mathrm{Cr}, \mathrm{Mo}, \mathrm{W} ; \mathrm{M}^{\prime}=\mathrm{Na}$ the encapsulated complex displays two sets of three $\nu \mathrm{CO}$ mid-IR absorption bands, each corresponding to one of the two most likely trapping sites illustrated below, by using similar site geometry nomenclature to that described earlier for $\mathrm{M}(\mathrm{CO})_{3}\left(\eta^{6}-\mathrm{C}_{6} \mathrm{H}_{6}\right)-\mathrm{Na}_{56} \mathrm{Y}$.
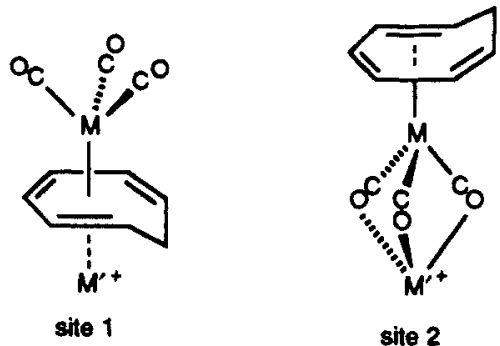

site 2

A representative set of mid-IR spectral traces which depict the above system for $\mathrm{M}=$ Mo shown below

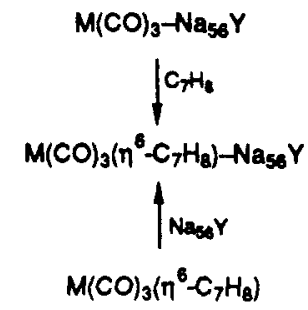

is illustrated in Figure 7. As expected site 1 is found to yield solution-like values for the $\nu \mathrm{CO}$ stretching frequencies, whereas site 2 displays a red shift of around $50 \mathrm{~cm}^{-1}$ for the $\nu C O$ stretching frequencies compared to the solution phase values (supplementary material Table V). W(CO $)_{3}\left(\eta^{6}-\mathrm{C}_{7} \mathrm{H}_{8}\right)$ is found to be anchored only in site 2 in $\mathrm{Cs}_{56} \mathrm{Y}$.

Finally in some preliminary measurements, $\mathrm{M}(\mathrm{CO})_{3}-\mathrm{Na}_{56} \mathrm{Y}$ is found to react with trimethylphosphine at $150^{\circ} \mathrm{C}$ to give $C_{s}$ symmetry tricarbonyltris(trimethylphosphine)metal $(0)$ complexes confined in the $\alpha$-cage of the zeolite Y, as illustrated below:

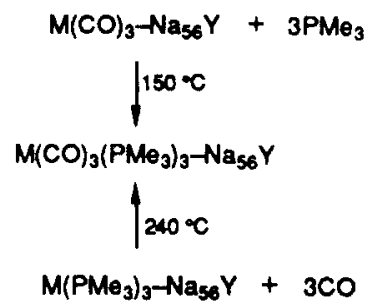

From the mid-IR spectra recorded during the course of the reaction one observes that the final product is formed in THREE steps, through reaction intermediates that are best ascribed to $\mathrm{M}(\mathrm{CO})_{3}\left(\mathrm{PMe}_{3}\right)_{1,2}-\mathrm{Na}_{56} \mathrm{Y}$. Characteristic $\nu \mathrm{CO}$ and $\nu \mathrm{CH}$ stretching frequencies for $\mathrm{M}(\mathrm{CO})_{3}\left(\mathrm{PMe}_{3}\right)_{3}-\mathrm{Na}_{56} \mathrm{Y}$ and its cleanly formed vacuum thermal decarbonylation product proposed to be $\mathrm{M}\left(\mathrm{PMe}_{3}\right)_{3}-\mathrm{Na}_{56} \mathrm{Y}$ are summarized in supplementary material Table II. By comparison of the former with their solution-phase counterparts it would appear that $\mathrm{M}(\mathrm{CO})_{3}\left(\mathrm{PMe}_{3}\right)_{3}-\mathrm{Na}_{56} \mathrm{Y}$ are attached to the zeolite framework through an interaction of the oxygen end of their carbonyl ligands with an extraframework $\mathrm{Na}^{+}$ cation. More detailed studies of the encapsulated $\mathrm{M}(\mathrm{CO})_{3}\left(\eta^{6}-\right.$ $\left.\mathrm{C}_{6} \mathrm{H}_{6}\right), \mathrm{M}(\mathrm{CO})_{3}\left(\eta^{6}-\mathrm{C}_{7} \mathrm{H}_{8}\right), \mathrm{M}(\mathrm{CO})_{3}\left(\mathrm{PMe}_{3}\right)_{3}$, and $\mathrm{M}\left(\mathrm{PMe}_{3}\right)_{3}$ complexes will be required to establish intimate details of the 
geometry of their anchoring sites, dynamics, and reactivity in zeolite $Y$.

\section{Conclusions}

The key points to emerge from this study are summarized in point form below: (i) $\mathrm{M}(\mathrm{CO})_{6}-\mathrm{M}_{56}^{\prime} \mathrm{Y}$ samples have the hexacarbonylmetal $(0)$ guest anchored to two $\alpha$-cage extraframework cations (or Bronsted protons) via the oxygen end of two trans bonded carbonyl ligands, with a saturation loading of $2 \mathrm{M}$ $(\mathrm{CO})_{6} / \alpha$-cage. (ii) $\mathrm{M}(\mathrm{CO})_{6}-\mathrm{M}_{56}^{\prime} \mathrm{Y}$ have the hexacarbonylmetal $(0)$ guest confined to the internal surface of the zeolite with an essentially homogeneous distribution running throughout the zeolite crystals. (iii) A Mo and Rb EXAFS structure analysis of $8\left\{\mathrm{Mo}(\mathrm{CO})_{6}\right\}-\mathrm{Rb}_{56} \mathrm{Y}$ shows that the structural integrity of the $\mathrm{Mo}(\mathrm{CO})_{6}$ guest is maintained in the $\alpha$-cage of zeolite $\mathrm{Y}$ with some evidence for anchoring via extraframework $\mathrm{Rb}^{+}$cations. (iv) Rapid ${ }^{13} \mathrm{CO}$ intrazeolite thermal and photoinduced ligand exchange occurs for $\mathrm{M}\left({ }^{12} \mathrm{CO}\right)_{6}-\mathrm{M}_{56} \mathrm{Y}$ to yield $\mathrm{M}\left({ }^{12} \mathrm{CO}\right)_{\mathrm{m}^{-}}$ $\left({ }^{13} \mathrm{CO}\right)_{6-m}-\mathrm{M}_{56}^{\prime} \mathrm{Y}$ the extent of which depends on the ${ }^{13} \mathrm{CO}$ loading. (v) $\mathrm{M}(\mathrm{CO})_{3}-\mathrm{M}^{\prime}{ }_{56} \mathrm{Y}$ can be cleanly generated via the mild vacuum thermal decarbonylation of $\mathrm{M}(\mathrm{CO})_{6}-\mathrm{M}^{\prime}{ }_{56} \mathrm{Y}$, the tricarbonyl stoichiometry of which is unequivocally established from its observed and calculated diagnostic $\mathrm{M}\left({ }^{12} \mathrm{CO}\right)_{n}\left({ }^{13} \mathrm{CO}\right)_{3-n}-\mathrm{M}_{56}^{\prime} \mathrm{Y}$ vibrational isotope patterns. (vi) Intrazeolite reactions of $\mathrm{M}$ $(\mathrm{CO})_{3}-\mathrm{M}_{56}^{\prime} \mathrm{Y}$ with large and small arenes, trienes and phosphines, cleanly yield the respective intrazeolite six-coordinate complexes (shown to be identical with the products of direct vapor phase impregnation of the latter complexes) thereby supporting the tricarbonylmetal( 0$)$ assignment as well as pinpointing the location of the $\mathrm{M}(\mathrm{CO})_{3}-\mathrm{M}_{56}{ }_{56} \mathrm{Y}$ tricarbonylmetal $(0)$ moiety on the internal surface of the zeolite. (vii) Cation effects in the mid/far-IR and optical reflectance spectra of $\mathrm{M}(\mathrm{CO})_{3}-\mathrm{M}_{56}{ }_{56} \mathrm{Y}$ indicate that the supercage confined $\mathrm{M}(\mathrm{CO})_{3}$ moiety is anchored to an oxygen framework six-ring site (B) rather than to an extraframework cation site via the metal (A) or oxygen end of the carbonyls $(\mathrm{C})$. (viii) A Mo and Rb EXAFS structure determination for 8 (Mo(CO) $\left.{ }_{3}\right\}-\mathrm{Rb}_{56} \mathrm{Y}$ confirms the oxygen framework anchoring site model B. (ix) The occurrence and origin of an observed $C_{3 v}$ regular trigonal-pyramidal to $C_{s}$ distorted trigonal-pyramidal structural change amongst the $15 \mathrm{M}(\mathrm{CO})_{3}-\mathrm{M}_{56}^{\prime} \mathrm{Y}$ samples can be rationalized with a second-order Jahn-Teller (SOJT) effect. (x) EXAFS data for the controlled thermal decomposition of $8\left\{\mathrm{Mo}(\mathrm{CO})_{3}\right\}-$ $\mathrm{Rb}_{56} \mathrm{Y}$ demonstrates the formation of molybdenum atoms statistically distributed in the zeolite lattice.

Acknowledgment. We wish to acknowledge the Natural Sciences and Engineering Research Council of Canada's Operating and Strategic Grants Programmes for generous financial support of this work. S.O. expresses his gratitude to the Middle East Technical University for granting him an extended leave of absence to conduct his research at the University of Toronto. K.M. and T.B. acknowledge partial funding for this work from the donors of the Petroleum Research Fund, administered by the American Chemical Society. The operational funds for NSLS beamline X-3 are provided by DOE Grant No. DEFG0286ER45231 and Grant No. DEFG0291ER45231. Supplies of high quality zeolites from Dr. Edith Flanigen at Union Carbide, Tarrytown, NY are gratefully appreciated. Technical assistance and valuable scientific discussions with Dr. Galen Stucky, Dr. Bill Harrison, and Mr. Jim MacDougall of the University of California at Santa Barbara on XRD powder diffraction and Rietveld refinement as well as molecular modelling on the CHEM-X system is also deeply appreciated. We also thank all of our co-workers at Toronto for many stimulating and enlightening discussions during the course of this work.

Supplementary Material Available: Experimental details and tables of observed $\nu \mathrm{CO}$ stretching frequencies and bond lengths and kinetic diameters and figures as described in the text $(28$ pages). Ordering information is given on any current masthead page.

\title{
Transition-State Stabilization and Molecular Recognition: Acceleration of Phosphoryl-Transfer Reactions by an Artificial Receptor
}

\author{
Paolo Tecilla, ${ }^{\dagger}$ Suk-Kyu Chang, ${ }^{\ddagger}$ and Andrew D. Hamilton* \\ Contribution from the Department of Chemistry, University of Pittsburgh, Pittsburgh, \\ Pennsyluania 15260. Received February 16, 1990
}

\begin{abstract}
An artificial receptor that is complementary to the proposed trigonal-bipyramidal intermediate for phosphoryl-transfer reactions has been designed. Kinetic measurements with ${ }^{31} \mathrm{P}$ NMR methods show that the receptor causes up to a 10 -fold acceleration in the aminolysis of phosphorodiamidic chloride derivatives, proceeding via an associative mechanism.
\end{abstract}

\section{Introduction}

Enzyme catalysis depends upon the preferential complexation and stabilization of transition states over their corresponding starting materials and products. ${ }^{1}$ An important goal in the development of artificial enzymes must, therefore, involve the construction of synthetic receptors that are complementary to the

\footnotetext{
Permanent address: Dipartimento di Chimica Organica, Università Degli Studi di Padova, Padova, Italy.

tPresent address: Department of Chemistry, Chung-Ang University, Seoul, Korea.
}

electrostatic and spatial features of transition-state structures. ${ }^{2}$ Such receptors would be expected to show substantial rate accelerations of those reactions with complementary transition states. $^{3}$ The success of this approach depends on the precise

(1) Pauling, L. Chem. Eng. News 1946, 24, 1375. For more recent discussions, see: Schowen, R. L. Transition States in Biochemical Processes; Gandour, R. D., Schowen, R. L., Eds.; Plenum Press: New York, 1978; pp 77-114. Kraut, J. Science (Washington, D.C.) 1988, 242, 533-540.

(2) For an illuminating discussion of these goals, in general, and phosphoryl transfer reactions, in particular, see: Boger, J.; Knowles, J. R. Ciba. Found. Symp. Mol. Interact. Act. Proteins 1978, 60, 225-242. 